\title{
A Study of the Life History and Ecology of the Round-Tailed Muskrat (Neofiber alleni True) in North Central Florida
}

By

\section{DALE EUGENE BIRKENHOLZ}

\begin{abstract}
A DISSERTATION PRESENTED TO THE GRADUATE COUNCIL OF THE UNIVERSITY OF FLORIDA IN PARTIAL FULFILLMENT OF THE REQUIREMENTS FOR THE DEGREE OF DOCTOR OF PHILOSOPHY
\end{abstract}

UNIVERSITY OF FLORIDA

February, 1962 


\section{ACKNOWLEDGMENTS}

I wish to express sincere gratitude to Dr. James $\mathrm{N}$. Layne for the untiring and valuable guidance given in directing this study. Additional assistance by Drs. Pierce Brodkorb, Archle Carr, Albert Laessle, Carl Monk, and James Redmond is deeply appreclated. I am indebted to the following persons for aid in ldentifying parasites and nest associates: Dr. L. A. Hetrick, University of Florida (insects); Dr. John McCrone, Farleigh Dickinson University (spiders); Dr. R. A. Strandtmann, Texas Technological College (mites); and Dr. G. W. Hunter, University of Florida (endoparasites).

Mr. R. L. Henderson of Gainesville, Florida, gave me access to his property on Paynes Prairie for the study. His generosity contributed in great measure to the success of this work and is deeply appreciated.

Thanks are given to the following associates who assisted with various aspects of the study: Mr. Howard Hutchinson, Dr. Donald Jenn1, Mr. Robert MacFarlane, Dr. Robert Mount, Mrs. Ellzabeth Wing, and Mr. William Wirtz.

This research was supported in part by a National Science Foundation Summer Fellowship for Graduate Teaching Assistants in 1960 and by grants from Sigma X1 and the Florida Academy of sciences. 
TABLE OF CONTENTS

Page

ACKNOWLEDGMENTS

LIST OF TABLES

LIST OF ILLUSTRATIONS

INTRODUCTION

MATERIALS AND METHODS

DESCRIPTION OF THE STUDY AREA . . . . . . . . . . . .

History

vegetation

study sites

Phenological Habitat Changes

climate and Weather

Associated Vertebrate Fauna

SIZE AND WEIGHT CHARACTERISTICS OF THE PAYNES PRAIRIE POPULATION

Seasonal Variations in Weight and Measurements

HOMESTTES

Houses

Feeding Platforms

Feeding Shelters

Burrows

ACTIVITY . . . . . . . . . . . . . . . .

Daily Activity

Seasonal Activity

FOOD

MOVEMENTS

Home Range

Territoriality

Dispersal 
POPULATION DENSITY AND COMPOSITION . . . . . . . . 60

History

Density

Sex Ratios

Age structure

REPRODUCTION . . . . . . . . . . . . . . . . .

Age and Cyclic Changes in Reproductive organs

Breeding Seasons

Estrus Cycle

Mating Behavior

Gestation Period

Litter size

Number of Iitters Per Year

Natality

GROWTH AND DEVELOPMENT . . . . . . . . . . . . .

Growth

Physical and Behavioral Development

Pelage and Molts

Comparison of the Growth and Development of Neo-

fiber with other Microtine Rodents

MORTALITY FACTORS . . . . . . . . . . . . .

Environmental Conditions

Predation

Parasites and Disease

Social Interaction

Relative Roles of Mortality Factors in Population Regulation

DISCUSSION . . . . . . . . . . . . . .

SUMMARY . . . . . . . . . . . . . 140

LITERATURE CITED . . . . . . . . . . . . . 143

BIOGRAPHICAL SKETCH . . . . . . . . . . 149 


\section{LIST OF TABLES}

Table

Page

1. External measurements, in mm., of $108 \mathrm{male}$ and

94 female, and welghts, in grams, of 108 male and 52 non-pregnant female Neofiber alleni

from Paynes Prairie study area......

2. Age and reproductive classification of Neofiber alleni captured on Paynes Prairie study area November 1958 to December 1960 . . . . .

3. Instantaneous growth rates of seven young Neo-

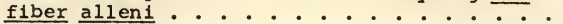

4. Chronology (in days) of some developmental landmarks of several species of microtine rodents 


\section{LIST OF ILLUSTRATIONS}

Figure

Page

1. (Upper) Paynes Prairie study area . . . . . . . 9

2. (Lower) closer view of typical prairie habitat . 9

3. Paynes prafrie study area . . . . . . . . 12

4. Composition of emergent vegetation in relation to water depth in shallow marsh on paynes Prairie

5. Monthly averages of rainfall on Paynes prairie in 1959, 1960, and for a 51-year period.....

6. Average daily maximum and minimum temperatures in the Gainesville region, 1960, and the 51-year average .. . . . . . . . . . . .

7. Frequency distribution of weights of adult Neo主ber alleni from Paynes Prairie.......

8. Variation in length and weight of adult male and female Neoflber allent by month . . . . . .

9. (Upper) Typical Neofiber house in a PanicumPontederia habitat... . . . . . . .

10. (Lower) Typlcal Neofiber feeding platform in same habitat as above... . . . . . . . . .

11. (Upper) Interior of house of non-breeding Neoflber ... . . . . . . . . . . . 34

12. (Lower) Interior of house used for raising young 34

13. Means and ranges of outside temperatures and those within the interior of ten occupied Neofiber houses at different times of the day.....

14. Testis length of Neofiber alleni in relation to body weight, age class and fertility.....

15. (Upper) Percentage of adult female Neofiber pregnant by month ................ 
16. (Lower) Composition of monthly samples of all Neoflber alleni collected from Paynes Prairie 80

17. Increase in weight of seven young Neofiber allent 91

18. Growth of seven young Neofiber allent according to 4 linear measurements........... 92

19. Instantaneous growth rates of representative microtine rodents . . . . . . . . . 93

20. Young Neoflber allen1 . . . . . . . . . . 97

21. Molt patterns in Neofiber allen1 . . . . . . . 104

22. (Upper) Percentage of total area of all adult Neofiber pelts molting in each month of the study 109

23. (Lower) Percentage of adult pelts showing some degree of molting in each month of the study . 109

24. (Upper) study area at Station 2 after heavy rains in mid-March 1960 ........... . 116

25. (Lower) Heavy concentration of Neofiber houses in Panicum marsh at Station 2 in November 1959. . 116

26. (Upper) Panicum hemitomon habitat at station 2 during dry period of rune 1961 . . . . . . 121

27. (Lower) Area formerly containing deeper water at Station A in June 1961 . . . . . . . . 121 


\section{INTRODUCT ION}

The round-tailed muskrat (Neoflber alleni True) was discovered near Georgiana, Brevard County, Florida, in December 1883 and described the following year by Frederick True (1884a) who designated it ". . a living link between the

muskrat and the field mouse." Only the grassy marshes, or prairies, of Florida and extreme southeastern Georgia constitute its present range.

Early fragmental observations on the characteristics and natural history of the round-tailed muskrat subsequent to its discovery were made by True $(1884 \mathrm{~b}, 1885)$, Baker (1889), Chapman (1889, 1894), Miller (1896), Bangs (1898), Bailey (1900), and Elliot (1901). Later contributions by Harper (1927) in the okefenokee Swamp of Georgia, and Rand and Host (1942), Moore (1946), Schwartz (1952, 1953), and Porter (1953) in Florida provided additional information about this mammal. Porter's study was the first work devoted entirely to the life history of Neofiber. Despite these contributions, however, the round-tailed muskrat has remained one of the least known of North American small mammals.

The present study was conducted from october 1958 through August 1961. Although supplementary observations were made in Broward, Highlands, and Putnam Counties, the investigation was centered in north central Florida in the 
- vicinity of Gainesville, Alachua County. Nearly all observations and collecting in this region were carried out on Paynes Prairie, six miles south of the University of Florida campus. The animals in this population are referable to the nominate subspecies (Schwartz, 1953). While most aspects of the biology of the species were investigated, particular emphasis was placed on reproduction, growth, and ecology. Directing attention to a particular population made it possible to obtain more systematic and detailed information regarding the animal's habits than a more general survey would allow. The phylogenetic relationships and zoogeographic history of this unique rodent are little known, and it was hoped the more comprehensive data on 1ts biology might contribute to a better understanding of the role of ecologic factors in its evolution and distribution. 
MATERIALS AND METHODS

Most specimens for laboratory examination were obtained by trapping with Victor No. 0 underspring steel traps and Victor No. 110 Conibear traps. Houses or covered feeding shelters were carefully opened from the top, and a trap was placed inside. The opening was then repaired. Traps were sometimes placed in runways or on feeding pads. They were spaced 3 to 50 feet apart, depending upon the amount of sign present, and the trap sites were marked with 5-foot bamboo poles. Trapping activities were shifted between different stations of the study area, and specimens were taken in every season. For the entire study trapping success was about 25 per cent, varying from 10 per cent in warm weather and in areas of dense cover to 50 per cent after rises in water levels, at which time most houses still intact were occupied.

All specimens collected were welghed, measured, and examined for ectoparasites, injuries, and abnormalities. Reproductive tracts were fixed in Bouin's or formalin, alcohol, and acetic acid (Lavdowsky's mixture) and stored in 70 per cent ethyl alcohol or FAA for later sectioning. The condition of vulva, tubal genitalia, ovaries, mammary tissue, and teats were recorded for females. In males, developmental condition of the testes, cauda epididymides and accessory glands were noted. Smears of cauda epididymis were made and 
examined for presence of sperm until it was established that enlarged epididymal tubules invariably indicated the presence of mature sperm. All ovaries and testes, and samples of uteri and male accessory glands representing different stages of the reproductive cycles were sectioned at $15 \mathrm{ml}-$ crons and stained with hematoxylin and eosin.

The remaining viscera were examined for food, parasites, and evidence of disease or abnormalities elther at autopsy or after preservation in 10 per cent formalin. Weights of heart, kidney, liver, lungs, and spleen were obtalned from a representative series of animals. Standard museum skins or flat skins were prepared, and skeletons were cleaned by dermestid beetles or maceration. Data for each specimen were recorded on McBee keysort cards, which were later coded.

A total of 384 round-talled muskrats were trapped from the Paynes Prairle study area from October 1958 to August 1961. Seven Individuals were also trapped from another area. Analyses of catch composition and size, parasites, and reproductive data were made on 326 individuals taken through December 1960. Monthly samples averaged 27 with a range of from 16 to 44 . Fifty additional animals, taken by hand or nets along roadways and shorelines during two periods of early spring flooding, were not included in the above analyses.

AnImals were live trapped for home range study and for the laboratory colony. The traps, 4 inches high, 4 inches wide, and 8 inches long, were constructed of hardware cloth and held an inward-swinging wire door in one end. They were 
placed in the exit hole of a house or feeding platform so that an animal swimming to the structure pushed the door inward and became trapped upon entering the cage. Since houses were damaged or destroyed while capturing the animals and trapping success was low, this method could not be used for population studies. Data on movements were obtained by injecting radioactive phosphorus into live-trapped animals, which were then released. Nightly movements of these individuals were traced by monitoring feeding platforms for radioactive fecal pellets.

A total of 36 animals were kept in captivity at various times. Most fared well in captivity. They were housed in wire cages 24 inches square and 12 inches high. A 10 by 16inch shallow pan for water and food was fitted into the bottom. A nest box or jar was placed inside each cage, with sawdust and hay provided for bedding. Lettuce, carrots, potatoes, and commercial rat pellets were fed daily. The first 3 foods were accepted immediately, but several weeks passed before the animals accepted rat pellets. They were particularly fond of fresh sweet corn which was fed occasionally. During the first year several animals died on a diet of raw potato; but after the more varfed fare was given, most thrived.

Water was provided in finger bowls. The animals habitually defecated in the water bowls which had to be cleaned each day. Drinking tubes were provided at first, but this was discontinued because the animals plugged the openings. 
The study area was visited at regular intervals to make observations on dispersal of populations, types of houses prevalent, amount of house building, food remains on feeding platforms, evidence of predation, seasonal cover changes, associated fauna, fluctuations of water levels, and other aspects. Perlodic live trapping was conducted to study the small mammal associates in this habitat. 


\section{DESCRIPTION OF THE STUDY AREA}

The habitat afforded by Paynes Prairle (F1gs. 1 and 2), where the principal portion of this study was conducted, resembles some localities in the Everglades and is typical of many of the prairies in central and southern florida.

\section{History}

Paynes Prairie is an oval, saucer-shaped basin of approximately 13,000 acres. It has a firm sandy bottom and is underlain by porous Ocala limestone. Solution has produced numerous sinks and underground channels in the general area. The prairie, termed by Wllliam Bartram in 1774 (Van Doren, 1928) as the Great Alachua Savannah, was then a nearly level, treeless, wet plain. Water levels often were high enough during the spring that a wave-swept shoreline was developed on one side. It was actually a lake in the late 1800's. These changes seem to have been a result of the opening and plugging of a large sink at the east end of the prairie. At present, because of grazing interests, the sink is kept open, and seasonal fluctuations in water levels are minimized by pumping and construction of a levee at the east end. The present aspect of the prairle appears to be similar to that described by Bartram, except for the presence of fences and a modern 4-lane highway crossing the center. 
Figure 1.--(Upper) Paynes Prairie study area. Light colored area is the drier pasture land and grassy marsh. Darker areas are the deeper ponds and sloughs with cover mostly of Pontederia lanceolata.

Figure 2.--(Lower) closer view of typical prairie habitat. Dense stand of Panicum hemitomon in foreground is ideal Neofiber habitat. 

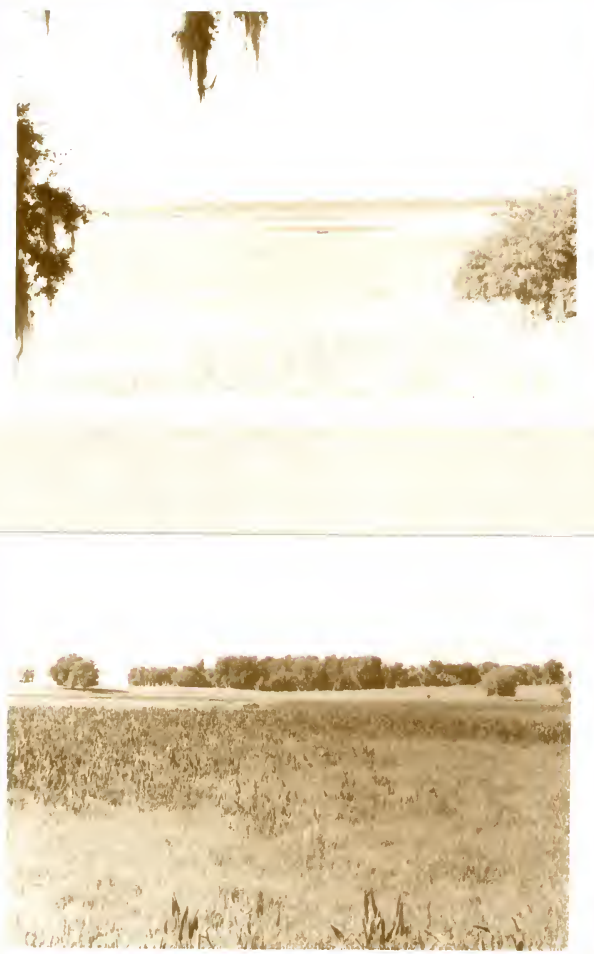
The center of the prairie contains an extensive marsh approximately 2 miles wide and 4 miles long (F1g. 3 ). In the pastured land between this area and the periphery of the prairie are many shallow ponds and sloughs. Most water areas range to 24 inches in depth, although some are deeper. They possess characteristics of the submergent and emergent hydroseres of both flatwoods ponds and river succession described by Laessle (1942). These stages persist when fires are frequent, but on the prairie grazing and water level fluctuations may accomplish much the same. Much of the prairie is now heavily grazed, and the grass cover is often cropped severely. By early spring some higher pastures resemble lawns in appearance, and the ponds and sloughs are often devold of emergent cover.

The prairie is still susceptible to flooding and drought. During this study, however, water levels fluctuations seldom exceeded 6 inches except in the summer of 1961 when most of the prairie became dry.

\section{Vegetation}

Nomenclature of grasses follows that of Hitchcock (1950); the other vegetation that of Eyles and Robertson (1944) or Small (1933).

The deepest ponds contained open water or beds of water hyacinth (E1chornia crassipes) at the surface and furnished no habitat for Neofiber. Water areas about 18 to 24 inches deep were characterized by nearly pure stands of pickerelweed (Pontederia lanceolata), mats of Hydrophyllum 
离

๑

站

(1)

$+0$

ฮี

\&

क्रू 0

$+$

०.

$+8$

4

กี่

דi

(2)

(5)

0 'ृ

द

म

(1) क्ष

म 0

$\pi+4$

入

7 0

is 5

ए 30

㭊.

io is

क्षे द्ध

os 4

0)

ट

बन्व

क. 8 .

10

130

लं न

(1)

4 芩

วิ 0

क्र

a 1 is

in

0

कू है 


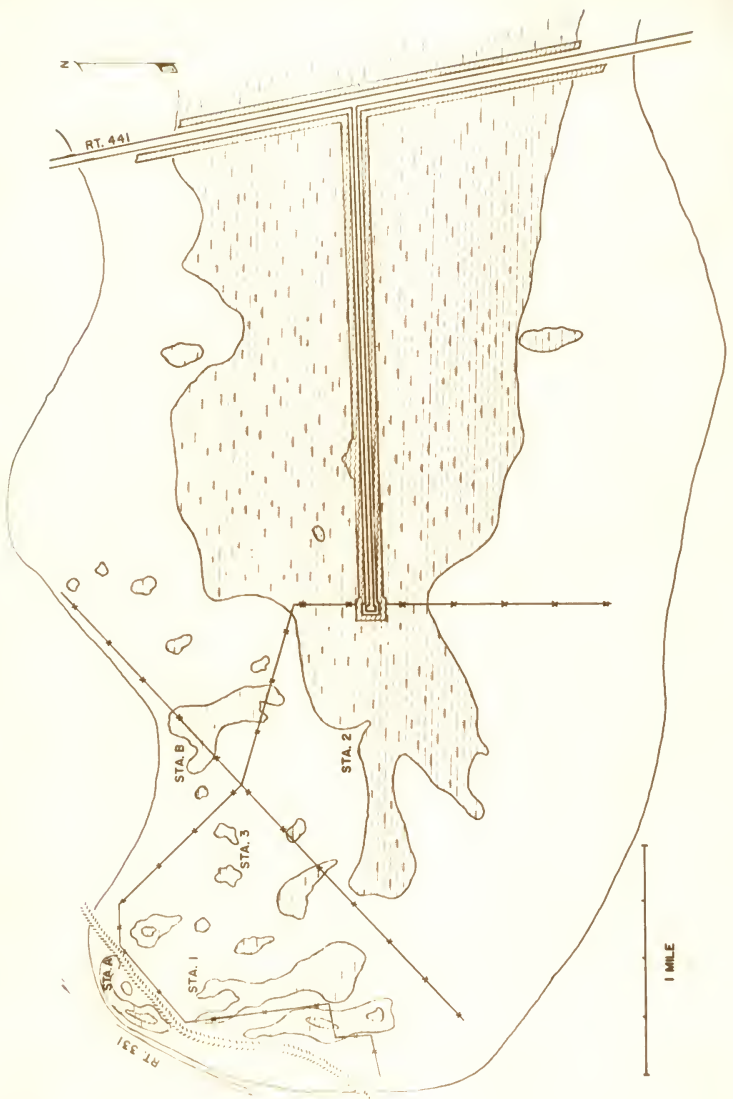


caroliniensis, and sparse growths of cutgrass (Leersia hexandra). Areas 6 to 18 inches deep were dominated by maldencane (Panicum hemitomon) and cutgrass and also contained beds or scattered plants of Hydrotrida caroliniana, Sagittaria lancifolia, Xyris difformis, and pickerelweed. In bordering meadows, broomsedge (Andropogon virg1nicus) was most abundant; Eleocharis spp., Cyperus flavenscens, Kyllinga odorata, Rhynchospora microcephala, R. fascicularis, Fibristylis Drummondii, Setaria geniculata, Digitaria sp., Sporobolus Poireti1, Eragrostis sp., Paspalum notatum, Rhexia sp., and Ludwigla suffruiticosa were also present.

Many species occurred only sporadically or were not as restricted to specific water depths as the former. These included Ricciocarpus natans, water-shield (Brasenia Schreberi), spatterdock (Nymphoides aquaticam), white water$111 y$ (Nyphaea odorata), lotus (Nelumbo lutea), coontail-moss (Ceratophyllum demersum), water-milfoil (Myrlophyllum heterophyllum), Juncus effusus, bog-moss (Mayaca fluviat1lis), water pennywort (Hydrocotyle umbellata), Polygonum hirsutum,

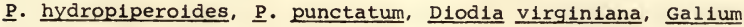
tinctorium, Jussiaea leptocarpa, buttonbush (Cephalanthus occidentalis), and Amphicarpum muhlenberglanum. Except in the deepest water, the ponds were usually choked with the above vegetation.

The general aspect of the study areas during the growing season appeared that of a single dominant, shallow, grassy marsh, with scattered pickerelweeds, the latter 
becoming dominant in the deeper areas. The single dominant aspect described is probably enhanced by vegetative reproduction by rhizomes, which contributes to the dense, almost pure stands of many species.

Soll samples taken at five water depths (from 6 to 22 inches) indicated that the substrate was a primary factor delimiting the vegetation. The soll was of pure sand under the Panicum zone. A progressively thicker mantle of muck covered the sand in deeper water. In 22 inches of water, where Pontederia and Hydrophyllum constituted the principal vegetation and the emergent grasses occurred only sporadically, the layer was about 3 inches thick. The relation between soll type, water depth, and vegetation is shown in Figure 4 and is evident in Figure 2.

\section{Study Sites}

Most field studies were conducted on approximately one square mile of the northwest corner of paynes Prairle. One principal area for the collection of specimens, designated Station 2, was a corner of the large center marsh with its relatively continuous, nearly pure stands of Panicum hemitomon. At the west edge of the prairie, a small pond with an adjoining larger slough was denoted as station 1 . Most of this area consisted of a Panicum-Pontederia mixture. A series of small, disjunct marshy ponds separated from each other by drier pasture land comprised station 3. Population and census studies were facilitated by these ponds, some of which were several hundred feet distant from each other. 


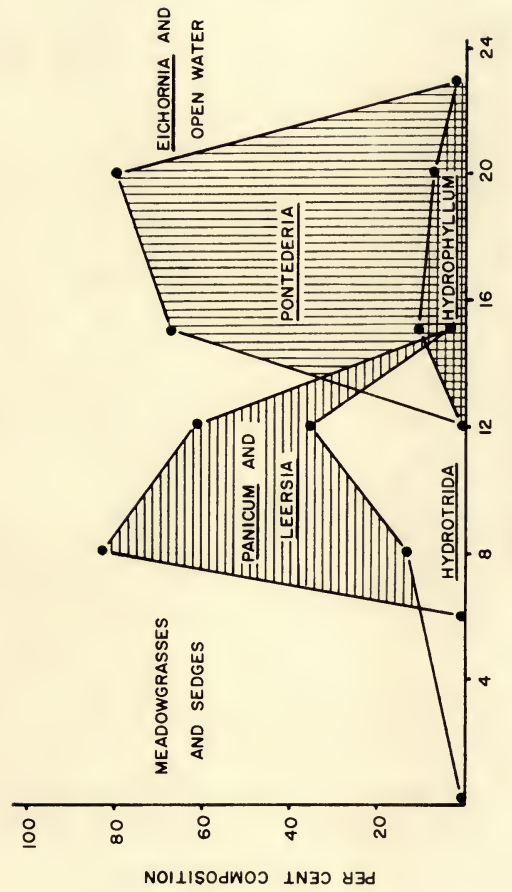

年 달

$\rightarrow 0$ व $+4$ 30 o 요 
Two sloughs in close proximity to a road contained all of the above vegetation and were used for dally censuses and other population studies. These, designated as Stations $A$ and $B$, contained all the vegetational zones and provided excellent opportunities to obtain data on the relationship of Neofiber populations to specific habitats. A narrow levee road extending into part of station 2 was particularly valuable for collecting and observation when high water drove animals to these roadbanks.

\section{Phenological Habitat Changes}

In March the first stems of Leersia hexandra appear above the surface of the water. By May, when the above species is about 6 to 12 inches high, the first panicum hemitomon and Pontederla appear. By mid-summer each species comprises about 50 per cent of the grass stand. By fall maldencane constitutes nearly all of the emergent grassy cover. In late summer the grasses and pickerelweed attain helghts of 18 to 24 inches, with some pickerelweeds being as tall as 36 inches. By this time the surface of most ponds is nearly obscured by the dense stands of emergents.

Frost usually occurs in the Galnesville area in early December (40-year average, December 4). Soon the breakdown of pickerelweed stalks begins, and by January only the dead grasses furnish emergent cover. Rain, time, water fluctuations, and grazing reduce the remaining emergent vegetation so that little usually remains by March. These cover cond1tions affect the extend to which new houses are bullt, type 
of feeding platforms constructed, and vulnerability of the Neofiber populations to flooding.

\section{Climate and weather}

The geographic area within which Neofiber is confined is one of subtropical climate (U.S.D.A., 1941). In the Gainesville region the growing season averages 285 days in length. Average yearly rainfall for a 51-year period is 50.73 1nches. The monthly distribution of ralnfall during the period of this study, together with the 51-year average, is given in Figure 5. Normally most rain falls during the summer. However, abnormally high rainfall occurred in March 1959 and 1960, resulting in flooding on the study area. Water levels dropped during the extremely dry May of 1960. During the drought of May and June 1961, most of the study area dried up, and the Neofiber population was practically wiped out. Although exceptions to normal conditions, these unusual weather patterns afforded an opportunity to assess the effects of extreme environmental conditions on the animals.

Summer temperatures (Fig. 6) and humidities are high in the Gainesville area. In winter, humidities are lower, and freezing temperatures occur only occasionally. The winter months may be characterized by short periods with temperatures considerably lower than indicated on the graph. During the study, temperatures averaged near normal, and ice formed a solid, but thin, layer on the study ponds only once, on January 31, 1959. The water was not frozen beneath Neofiber houses. 


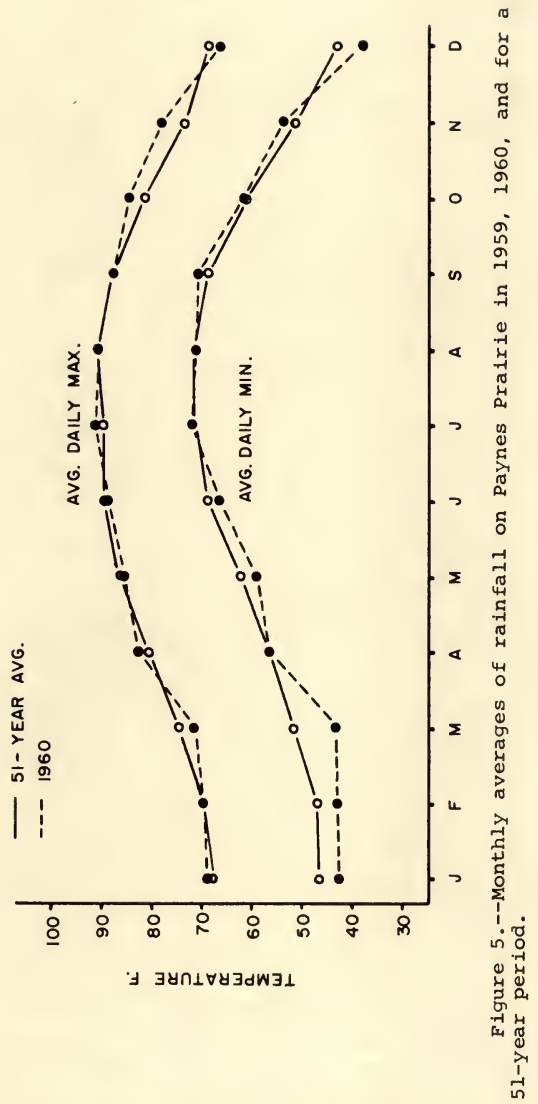




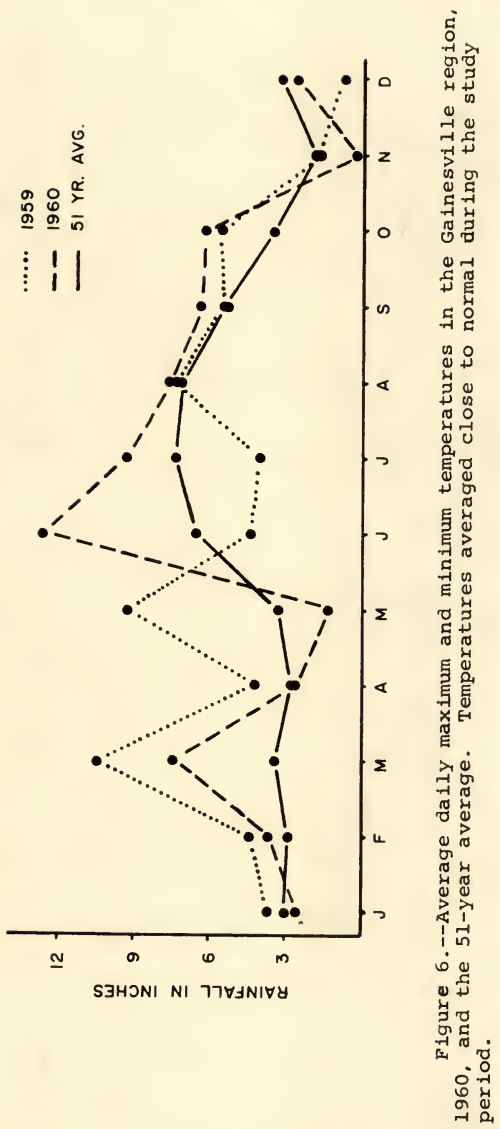




\section{Associated Vertebrate Fauna}

In addition to the round-talled muskrat, cotton rats (S1gmodon hispidus), rice rats (oryzomys palustris), and marsh rabbits (Sylvilagus palustris) occupied the wetter habltats on Paynes Prairie. Rabbits were common only where brushy cover existed and were rarely found in the grassy marshes. The other two species were found along marsh borders where grazing had not reduced the protective cover. The habitats of sigmodon and oryzomys overlapped broadly, but differences in their optimum habitats affected the relationships of both with Neofiber. Rice rats, while found in varlous habltats throughout their range (Hamilton, 1946), were restricted to the wetter margins of the marshes on the Paynes Prairie study area, but they also inhabited the marshes themselves. Cotton rats also utilized the wetter borders, but not the marsh proper. Other mammals common in the area were opossum (D1delphis marsupialis), raccoon (Procyon lotor), otter (Lutra canadensis), gray fox (Urocyon c1nereoargenteus), and bobcat (Lynx rufus). one mink (Mustela v1son) scat was found during the study. Breeding birds of the marshes of Paynes Prairie or adjacent pastureland included the least bittern (Ixobrychus exilis), Florida duck (Anas fulvigula), sandhill crane (Grus canadens1s), king rall (Rallus elegans), purple gallinule (Porphyrula martinica), common gallinule (Gallinula chloropus), killdeer (Charadrius voc1ferus), eastern meadowlark (Sturnella magna), red-winged blackbird (Agelaius phoeniceus), and boat-talled grackle (Cassidix mexicanus). 
The following birds were the most abundant visitants: great blue heron (Ardea herodias), common egret (Casmerodius albus), snowy egret (Leucophoyx thula), cattle egret (Bubulcus 1b1s), Loulsiana heron (Hydranassa tricolor), little blue heron (Florida caerulea), green heron (Butorides virescens), turkey vulture (Cathartes aura), black vulture (Coragyps atratus), red-tailed hawk (Buteo jamaicensis), red-shouldered hawk (Buteo lineatus), bald eagle (Haliaeetus leucocephalus), barn owl (Tyto alba), barred owl (Str1x var1a), and crow (Corvus brachyrhynchos). The most abundant winter visitants included American bittern (Botaurus lentig1nosus), marsh hawk (Clrcus cyaneus), common snipe (Capella gallinago), palm warbler (Dendrolca palmarum), pipit (Anthus spinoletta), and savannah sparrow (Passerculus sandwichensis).

Reptiles commonly encountered on the study area were the snapping turtle (Chelydra serpentina), striped mud turtle (Kinosternon bauri), cooters (Pseudemys floridana and $\underline{\text { P }}$. nelsoni), Florida softshell turtle (Trionyx ferox), green water snake (Natrix cyclopion), Florida water snake (Natrix sipedon), black swamp snake (Seminatrix pygaea), Florida brown snake (Storeria dekayi), garter snake (Thamnophis sirtal1s), ribbon snake (Thamnophis sauritus), striped swamp snake (Llodytes allen1), mud snake (Farancia abacura), black racer (Coluber constrictor), and eastern kingsnake (Lampropeltis getulus). The eastern cottonmouth (Agkistrodon p1scivorus) was seen only after floods and probably was not abundant. 
The most common amphibians noted were amphiuma (Amphiuma means), cricket frog (Acris gryllus), little grass frog (Hyla ocularis), chorus frog (Pseudacris nigrita), pig frog (Rana gryl10), and leopard frog (Rana piplens). The only fishes observed were topminnows (Heterandria and Gambusia), these being common in all waters. 


\section{SIZE AND WEIGHT CHARACTERISTICS OF THE}

\section{PAYNES PRAIRIE POPULATION}

The specimens collected from the paynes prairie study area were classified as juvenile, subadult, or adult, according to molt stage or pelage phase. Animals completing the subadult molt usually commenced breeding soon thereafter; hence, reproductive and pelage criteria were associated. The means and ranges in size and weight of adult male and non-pregnant female Neoflber are given in Table 1. These data include animals in good condition, possessing a moderate amount of body fat. Adult males averaged slightly heavier than females, the difference being significant at the 99 per cent confidence level $(t=2.77)$. There were no significant sex differences in linear measurements. The distribution of weights of adults (Fig. 7) indicates considerable variability (C.V. 12.7 for males, 14.6 for females).

Average size and weight of the upper 10 per cent of adult Neofiber are given as a reasonable maxima that might be attained in the Paynes Prairie population. For males, these values are: welght, $331.7 \mathrm{gms}$; body length, $212.2 \mathrm{~mm}$.: ta1l, $133 \mathrm{~mm}$; hind foot, $43.2 \mathrm{~mm}$; and ear from notch, 18.0 mm. Corresponding figures for females are: weight (nonpregnant), 324.0 gms.; body length, $213.7 \mathrm{~mm}$.; ta11, 130.6 mm.: hind foot, $42.7 \mathrm{~mm}$; and ear from notch, $18.0 \mathrm{~mm}$. The 
TABLE 1.--External measurements, in mm., of 108 male and 94 female, and weights, in grams, of $108 \mathrm{male}$ and 52 non-pregnant female Neofiber alleni from paynes Prairie study area.

\begin{tabular}{lcccccc}
\hline & \multicolumn{3}{c}{ Males } & \multicolumn{4}{c}{ Females } \\
\cline { 2 - 7 } Measurement & $\overline{\mathrm{X}}$ & Range & C.V. & $\overline{\mathrm{X}}$ & Range & $\mathrm{C} . \mathrm{V}$. \\
\cline { 2 - 7 } & & & & & & \\
Weight & 279.0 & $187-350$ & 12.7 & 262.0 & $192-357$ & 14.6 \\
Body Length & 200.7 & $183-220$ & 4.6 & 203.0 & $163-227$ & 4.7 \\
Ta1l Length & 123.0 & $95-142$ & 6.9 & 123.0 & $110-138$ & 5.6 \\
Hind Foot & 42.7 & $38.5-46.5$ & 3.7 & 42.0 & $38-45$ & 3.6 \\
Ear Notch & 18.0 & $15-20$ & 6.3 & 17.5 & $14-20$ & 6.0 \\
\hline
\end{tabular}




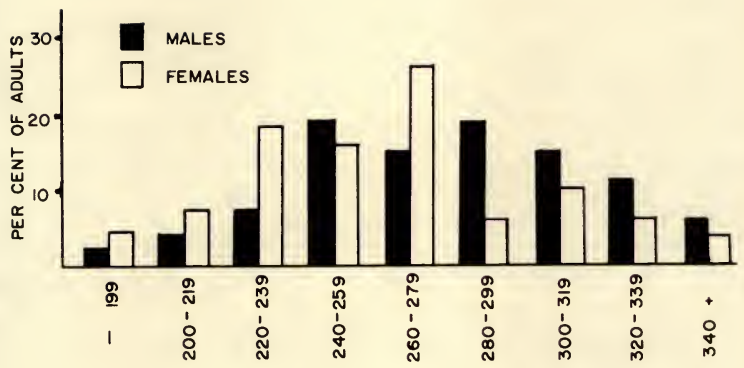

WEIGHT IN GRAMS

Figure 7.--Frequency distribution of weights of adult Neofiber allent from Paynes Pratrie. 
heaviest animal taken in this study (values for female in parentheses) weighed 350 (357) grams. Linear measurements of these individuals were: total length, 334 (342); tail, 124 (132); hind foot, 46 (45); ear from notch, 19 (18). Compared with measurements given in the literature, the Paynes Prairie population averages somewhat smaller than Neofiber from other areas. Porter (1953) recorded ranges in total length from 288 to $381 \mathrm{~mm}$. and in $\mathrm{h}$ ind foot from 38 to $50 \mathrm{~mm}$. Ranges given by Hall and Kelson (1959) are: total length, 285-381 mm.; ta11, 99-168 mm.; hind foot, 40-50 mm.; and ear from notch, 15-22 mm. Schwartz's (1952) largest specimens (TL 303-381) were from the panhandle of Florida (N. a. apalachicolae), the most northern and western population; but 3 of 4 of the measurements of his Dade County specimens from south Florida are equal to the maxima recorded by Porter and by Hall and Kelson. The basis of the smaller average size of individuals from the Paynes Prairie population may be genetic or environmental. It might also be due to the fact that the population was increasing at this time and therefore contained a larger percentage of younger an1mals. Johnson (1925) and Buss (1941), among others, have noted size differences between populations of the northern muskrat.

\section{Seasonal Varlations in Weight and Measurements}

Adults of both sexes were heavier in the fall and early winter than in spring and summer (Fig. 8). Since the average size of animals did not fluctuate greatly throughout the 


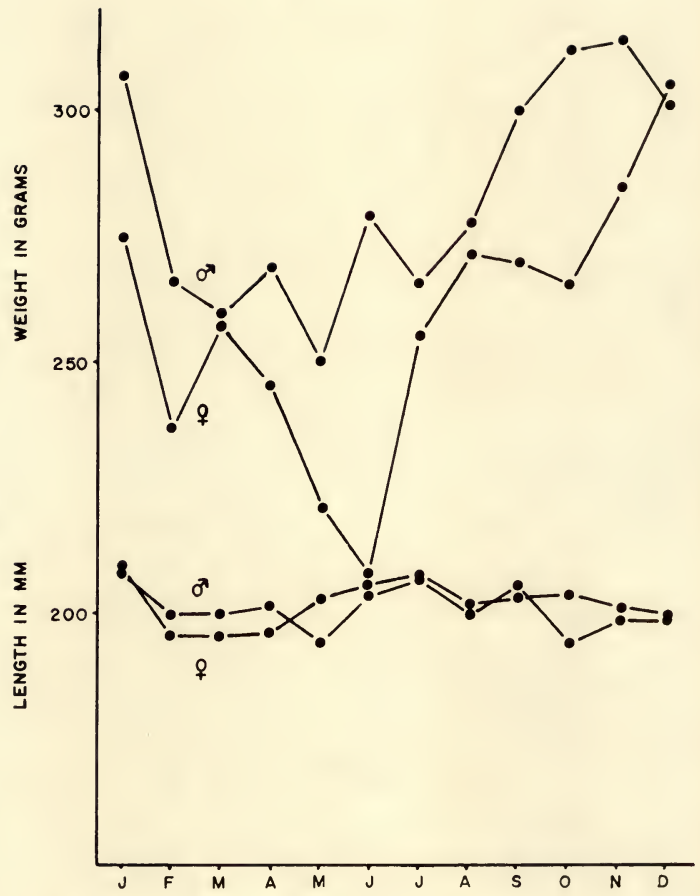

Figure 8.--Variation in length and weight of adult male and female Neofiber allent by month. 
year, increased weights in the latter part of the year probably were the result of plentiful food supplies and favorable temperature and water conditions rather than a change in age composition. Females varied more in weight than males throughout the year (S. D. of males 21.6, S. D. of females 25.6). The average weight of males taken in November was 25 per cent higher than the average of May specimens. December females averaged 46 per cent heavier than the June sample. I could not account for these differences. 
HOMESITES

The houses or lodges (Fig. 9), with the attendent feeding platforms (Fig. 10) and feeding shelters, comprise the homesites of the round-tailed muskrat. The house is used for shelter during the day and is normally occupied by one animal. The other structures are used for feeding purposes, defecating sites, and perhaps for resting at times. They may be shared. All of these structures are built of herbaceous vegetation.

\section{Houses}

Houses of Neoflber were first described by Baker (1889) and Chapman (1889). Bangs (1898), Elliot (1901), Harper (1920, 1927), Porter (1953), and Schwartz (1952) have supplied additional information. Houses were the predominant homesites of Neofiber on the Paynes Prairie study area. They were nearly spherical, although many of the larger structures became more dome-shaped, and were tightly woven of grasses or sedges. They generally rested upon a base of partly decayed vegetation or were constructed so as to be partially supported by standing vegetation. On my study area shrubs were not commonly used as support, as occurs in some areas. The houses ranged from 7 to 24 inches in diameter, averaging about 12 inches. The floor of the nest 
Figure 9.--(Upper) Typical Neofiber house in a PanicumPontederia habitat. Stems protruding from walls indicate fresh construction or repair.

Figure 10.--(Lower) Typical Neofiber feeding platform in same habitat as above. It is composed of Panicum hemitomon cuttings. 


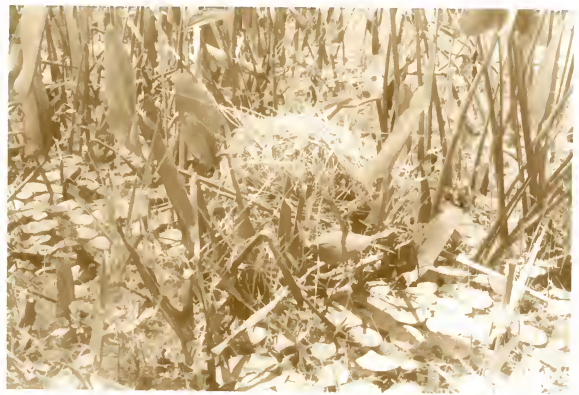

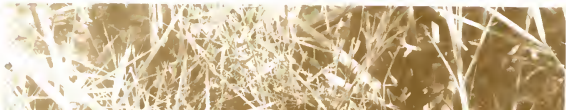

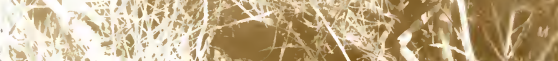

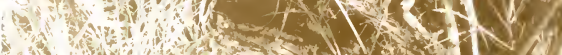

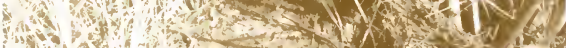

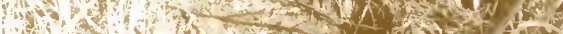

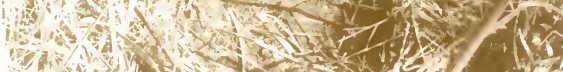

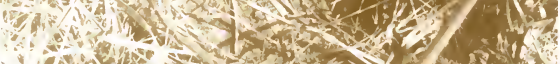

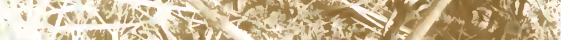

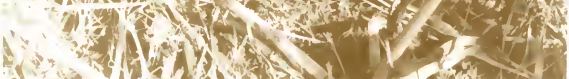


chamber was usually slightly above the water level, but some houses had more elevated interior chambers. The chambers were about 4 inches in diameter and normally contained two exit or plunge holes which led from the chamber to beneath the surface of the water. They might be on opposite sides of the chamber, or both along one side. A tunnel was formed by grass stems protruding from the exit holes and led beneath the surface of the water. The walls of the houses were strong, well woven, and difflcult to tear apart.

Two types of houses were constructed, one for ordinary living and the other for raising young. The walls of houses occupied by non-breeding animals generally were 2 to 3 inches thick. Grass stems and leaves formed the entire structure. The level of the floor ranged from water level to about 2 inches above, and the chamber was unlined and moist (Fig. 11).

Before parturition, females altered their houses by reinforcing the walls to as much as 6 inches in thickness and extending the floor of the chamber higher above the water. In some cases an additional chamber was added on top of the lower one. The chamber was lined with dry, fine-textured grasses (Fig. 12). During 3 years of field observations, recentlyfborn young and females in advanced pregnancy or in lactation were taken from this type of house in all but two cases.

Occasionally, larger and more complex structures were built. One such nest at Station A in october 1959, was 14 by 24 by 12 inches in size. A molst chamber with two exits 
Figure 11.--(Upper) Interlor of house of non-breeding Neofiber. Note lining of grass stems.

Figure 12.--(Lower) Interior of house used for raising young. Note lining of finely-shredded grasses. 

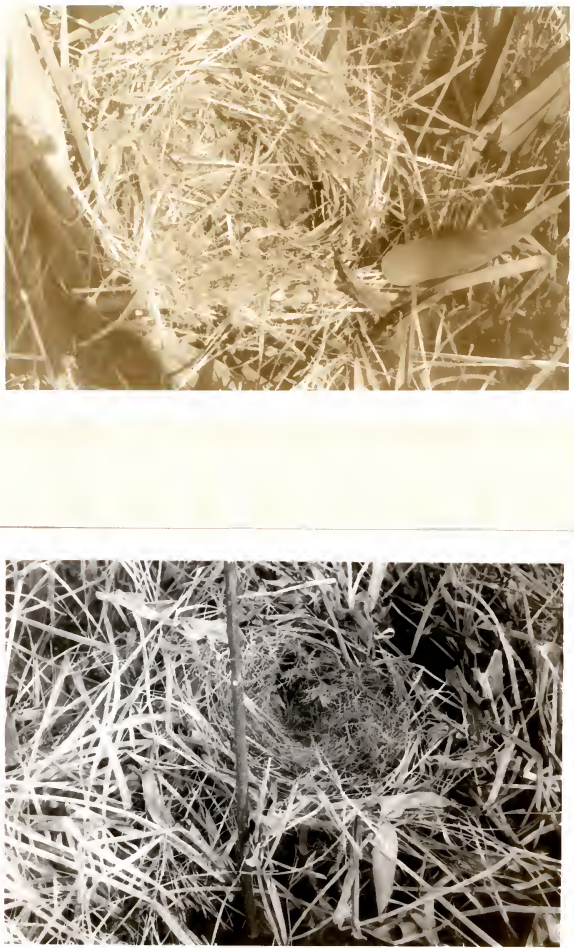
was present at one end. The center contained a low, wet room with two exits leading from each side. A short tunnel led from this room to a dry upper chamber. This house was occupied for more than 5 months, although during the last 4 weeks the smaller molst chamber was used only for feeding. Porter (1953) has also reported such complex houses belng bullt, usually in assoclation with fluctuating water levels. In his experience these structures were often anchored to tall shrubs.

\section{Materials used}

Plants previously reported to be used in the construction of Neofiber houses and feeding platforms include: sawgrass (Mariscus), Sporobolus spp.. Eleochar1s flacc1da, Rhynchospora tracy1 (Porter, 1953); Echinochloa, Pontederia, and Sagittaria lancifolia (Schwartz, 1952); and Erianthus and saw-grass (Scleria) (Harper, 1920). The principal house building material used on the study was maldencane, and this seems to obtain generally for north central Florida. Occasionally in early summer, the animals used Leersia hexandra and Hydrophyllum caroliniensis. These, along with maldencane, were the only common grasses present. At Station 1 in october 1959, three houses in a small bed of sedge (Cyperus sp.) were constructed entirely of this plant. On the small disjunct ponds at station 3 in late winter, when Panicum was scarce, muskrats used sedges, Ceratophyllum, and dried Polygonum stems to repair their houses. 
House environments

Measurements of temperature and humidity were made on a sample of ten Neofiber houses at Station A on 7 and 8 september 1960. Figure 13 gives the temperatures within and outside the houses at different times of the day. Early morning house temperatures were slightly higher than ambient temperatures, but during most of the day they were lower, as much as $10^{\circ} \mathrm{F}$. in some houses. By early evening house temperatures were again slightly above those outside the houses. Preliminary measurements indicated that temperatures were higher in unoccupied houses than in those being occupied and lined with fresh vegetation. The temperature of one abandoned house at 2:10 P.M. was 92 degrees, compared with 84 degrees in those classed as active.

Relative humidity was measured twice during the day, at 6:30 A.M. and 2:10 P.M., and was above the outside humidity at both times. It averaged 88 per cent in the houses and 84 per cent outside at 6:30 in the morning, and 70 per cent in the house and 58 per cent outside in the afternoon. The moist inner walls of most houses contributed to the higher humidities. These data indicate that the insulation provided by Neofiber houses may be of advantage in protecting the animal from high ambient temperatures during warm weather as well as aiding the animal in reducing heat loss during the winter. 


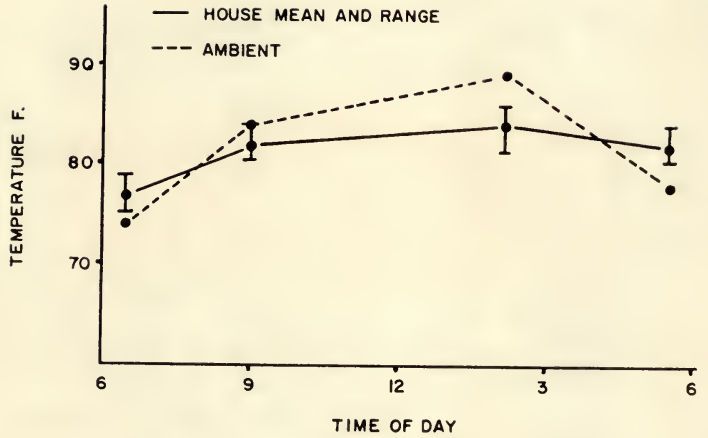

Figure 13.--Means and ranges of outside temperatures and those within the interior of ten occupied Neofiber houses at different times of the day. 


\section{Construction of houses}

I obtained data on house building by making periodic examinations of structures being built and, on one occasion, actually watching the beginning steps. Houses were assembled from a platform of freshly cut stems and debris. The surrounding grass was then bent inward to form a canopy over the platform. If the surrounding grass was dense enough, it sufficed to provide a temporary, crude shelter. On 25 March 1959, after flooding had displaced many animals on the study area, I watched an adult Neofiber, which was feeding on a platform at daybreak, assemble such a structure. The animal was hidden from sight in 10 minutes. As far as I could tell, it remained in the nest throughout the day, although the house could not be approached because of an intervening ditch. Normally construction continued until a more fin1shed structure was formed. The latter steps consisted of dragging grasses into the chamber where they were incorporated into the walls from within.

\section{Seasonal and age changes in houses}

The size of houses on Paynes Prairie exhibited some seasonal differences. In fall and early winter, when emergent vegetation was abundant, the houses were largest. In September 1958, house diameter averaged 14.5 inches at Station 1 and 12.5 inches at Station A. In May and July a sample of 47 houses at these stations averaged 10 inches in diameter. They averaged 7.4 inches in early August. Emergent vegetation became more abundant, and by August and september 
house diameters averaged 12.5 inches. Use of considerable Pontederia added to the bulk. While the differences in actual measurements do not seem great, the appearance of the houses at different seasons are markedly different. The larger houses exhibit a fresh, rough appearance, the new vegetation protruding through the walls from the interior.

In March 1960, many houses near the highway were larger than normal. Here, emergent cover was taller and more dense, and the rats added to their houses when water levels rose.

\section{Duration of house use}

Periodic observations made on a series of houses over a 6-month period gave data on length of house occupancy. The only information on the length of time Neofiber occuples their houses is Porter's (1953) statement that the larger dry-chambered houses may be used from year to year. In October 1959, a small population of animals at station A had located in a restricted stand of maidencane. The water was about 8 inches deep, and the area was surrounded by mixed marsh with pickerelweed and Hydrophyllum in water as deep as 30 inches. All houses were located on a map, marked, and examined for usage by carefully opening them.

on November 6 , two of the seven houses present were freshly built and contained moist chambers. Seven feeding pads were being used. One week later two occupled houses were being used only for feeding, one new house having been built nearby. On November 22, all houses were still being used as before. Water levels had remained static in this 
period, and even the same feeding platforms were used. By December 12, three previously occupied houses were being used as covered feeding shelters. Two houses, one bullt 3 weeks earlier, the other $(\mathrm{H}-1)$ active since observations began, were lined with dry grasses. On January 16, after 3 months of occupancy, the latter house was being used only for feeding, but a new molst-chambered house had been constructed 4 feet away. The 3-month interval coincides with the time needed to ralse a litter. The female evidently resided in the original house for more than 1 month before the dry lining was added. After 4 or 5 more weeks, it was abandoned. on February 4, house $\mathrm{H}-1$ was being used, and three other houses were reoccupied. By this time none of the original feeding platforms were active. One week later house $\mathrm{H}-1$ contained a dry, lined chamber, indicative of the production of a second litter. By February 20, because of receding water levels, most animals had moved into the adjacent deeper water. In early March heavy rains again raised water levels, and the area was reoccupied. By then the old houses had disintegrated.

From the above it was seen that some houses were used continuously for as long as 3 months, while others were used very intermittently. The latter were not occupied for regular periods which might indicate a regular shift from one house to another. After being deserted as homesites, houses may continue to be used for feeding purposes. Neofiber houses are apparently not used as long as those of ondatra, but they neither are as large nor require as much effort to construct. 
The amount of cover present affected the length of time houses were used. In March 1959 at station B, where only light grazing occurred and abundant previous year's vegetation existed, the animals did not raise or repair most of the flooded houses. Instead, they constructed new ones in the immediate vicinity many being no more than 3 to 4 feet from the original house.

\section{Relation of numbers of houses to numbers of animals}

House use was determined by censusing representative areas at station 2 and 3. A permanent transect, 8 by 62.5 feet was laid out across a representative segment of the pond at station 3. All houses in the transect were sampled weekly to determine their type and use. They were disturbed as 11ttle as possible. The censuses indicated that an average of two houses existed for every animal present. This was considered to be a minimum number of houses except in temporary situations caused by flooding.

At Station 2 in February 1960, when abundant emergent cover was present, 10 per cent of the houses occupied by Neoflber were breeding nests, 33 per cent were non-breeding nests, and 57 per cent were being used only for feeding. This indicates one round-talled muskrat in every two houses occupied by this species, or 37 per cent of the total, since oryzomys occupled some of the houses. Later in the spring, high water levels had forced oryzomys to drier habitats and destroyed many houses. Again, 50 per cent of the houses present were occupied by Neofiber. 
House associates

After being evacuated by muskrats, houses were readily claimed by both oryzomys and sigmodon. However, because of their preference for drier areas, cotton rats used only a few of the old houses in higher pastures. Rice rats, in addition to constructing their own shelters, occupied Neofiber houses in all habltats. In January 1960, 34 per cent of 80 Neofiber houses sampled at station 2 were occupied by oryzomys. As many as four individuals were present in a single house. Many of these houses were destroyed by water rises in spring, and the rice rats that remained spent the warmer months in small leaf and grass nests of their own construction.

The larger houses were altered when taken over by rice rats. The interior chambers were lined with finer grasses, and some were divided into smaller compartments. On several occasions Neofiber were captured in the lower part of modified house occupied by oryzomys. Rice rats also used the feeding platforms. During the winter, when more rice rats used Neofiber houses, mutilation of trapped muskrats by oryzomys was more common. Use of Neofiber houses by rice rats was first reported by Harper (1920) in the okefenokee. Their close association with ondatra has been mentioned by Stone (1898), Rhoads (1902), Ulmer (1944), and Harris (1953). Schwartz (1952) and Porter (1953) reported oryzomys and Sigmodon using Neofiber mounds and runways.

Several other vertebrates visited or used round-talled muskrat workings. Frogs (Rana grylio and $\underline{R}$. p1piens) were 
noted and also trapped in Neofiber houses on several occasions. Mud snakes (Farancia abacura) and water snakes (Natrix cyclopion and N. sipedon) were found in the chambers of houses. One small ribbon snake (Thamnophls sauritus) was found in the wall of a house. Natrix commonly were observed sunning themselves on housetops, especially on sunny winter days. While the frogs entered the shelters through the normal exits, many of the snakes entered through holes they made in the house walls.

The following vertebrates were reported by Porter (1953) to use Neofiber workings: salamanders (Manculus quadridigitatus), frogs (Rana clamitans and $\underline{R}$. pipiens), turtles (Kinosternon and Stenotherus), snakes (Natrix spp. and Agkistrodon piscivorus), and a skink (Eumeces inexpectatus). He also found a Peromyscus gossypinus in a house on one occasion. Harper (1935) collected a siren lacertina in a trap on a feeding platform.

Invertebrates were collected by placing the entire house in a plastic bag, then etherizing the contents. The houses were then taken apart and inspected, and the specimens preserved in 70 per cent ethyl alcohol. The arthropod fauna consisted primarily of spiders. Two of the most common species identified were Lycosa riparia and clublona maritima. The remainder, mostly small species, were not identified. Insects were common in the houses, and the following were identified: ODONATA: Libellulidae (nymphs); HEMIPTERA: Anthocoridae (adults), Reduvildae (nymphs), 
Velildae (nymphs); COLEOPTERA: Anobildae (adults), Hydrophilidae (adults), Staphylinidae (adults); HYMENOPTERA: Formicidae (adults); LEPIDOPTERA: Noctuidae (larvae), and DIPTERA: Syrphidae (pupae), Tabanidae (larvae). Leeches and snails were also common in the debris at the base of shelters. All of the above probably were incidental visitants, since the workings furnished the only shelter present in some seasons. None of the associates were potential predators.

only the relationship between Neofiber and oryzomys was considered common enough to be significant. Undoubtedly, the use of these houses by rice rats allows a larger population of the latter to survive the poor cover conditions which occur on most parts of the prairie in late winter and spring.

\section{Feeding Platforms}

Neofiber constructed one to six feeding platforms or stations (Fig. 10) near the houses. These structures consisted of a pad of vegetation, usually about 4 by 6 inches in size, which was barely elevated above the surface of the water. They served as feeding and defecation sites. Food remains were easily collected here, and in areas where populations were low approximate feeding areas could be delimited by plotting the location of the platforms. One or two plunge holes led from the platform to beneath the surface of the water. 
No selection of materials was noticed, except that the platforms seemed to be constructed of debris from feeding activities. The initial stage in construction appeared to be the formation of a tunnel leading from where food was gathered to the surface of the water. Gradually, grasses and other vegetation were deposited beside the hole until the platform was built. Materlals were added only when animals were using the platforms for feeding purposes. Otherwise, they might be visited, but were not repalred or added to. Food materials were dragged to the platform through the plunge holes.

\section{Feeding Shelters}

Neofiber also constructed small, crude feeding shelters. These were merely a feeding platform with a top. They averaged about 4 by 8 inches in size, the chamber being flush with or only slightly above the surface of the water. The plunge holes were located at the ends. Such feeding platforms were found at all times of the year, but were more common in late winter and spring when protective cover was at a minimum. Abandoned houses were sometimes used as feeding shelters. Sometimes the feeding platform was enclosed and used as a feeding shelter also; then later was formed into a house. However, this sequence was not always followed, and all feeding platforms did not result in completed houses. The platforms that resulted from feeding activities apparently offered good sites for house construction and were often utilized for this purpose. 


\section{Burrows}

Schwartz (1952) and Porter (1953) have described burrowing activities of Neofiber. Schwartz reported roundtalled muskrats living beneath the roadbed of the Tamiam Trail west of Miami in 1952. Although he mentioned the reason may have been because of cooler temperatures in the burrows, use of burrows seems to be mostly associated with drastic water fluctuations.

In this study burrowing occurred at Station 2 in June 1960 and 1961 when water levels dropped. A system of extensive burrows was maintained beneath the thick mat of vegetation covering the bottom. Most burrows and tunnels were filled with water, which was visible where the burrows came to the surface. The animals fed in the burrows and their side chambers, but also came out onto the surface of the vegetation. Similar situations have been described by Errington (1939a) for ondatra during droughts in central Iowa. Small numbers of round-tailed muskrats lived in burrows in the roadbank of a levee road that extends into the marsh at station 2 after being forced there by high water. From these data it seems that the animals can resort to a more terrestrial existence when forced to do so by environmental conditions. It is not known, however, for what period of time populations can exist under such conditions. Most of the population of Neofiber disappeared from the prairie after it had been dry for 6 weeks in the summer of 1961. 


\section{ACTIVITY}

Porter (1953) believed that Neofiber was most active from 8:00 P.M. until midnight. The animals were active during the day near Gainesville, where Bangs (1898) saw them building houses. In this study the behavior of captives, the estimated length of time since capture based on condition of the carcasses of trapped animals, and field observations furnished data on diel activity cycles.

\section{Da1ly Activity}

Captive animals became active about dark and immediately began to feed. Duration of feeding time varied, and they often carried food to their nest boxes. The night was spent alternately moving about the cage and sitting quietly, either inside or outside the nest box. Neofiber stayed in their nest boxes most of the day, except for brief trips to the water bowl to defecate.

Examination of trapped Neofiber in the morning indicated the animals were taken in traps at various times during the night, but the majority showed evidence of having been in traps for several hours and were most often captured the previous evening. Activity often was evident on the study area just before dark. Normally, traps were set just before dark, and at this time the sound of startled Neoflber diving 
beneath the surface was noted. Following floods Neofiber were often seen abroad during the day. Dlurnal activity also occurred to some extend under normal conditions. Animals were seen in daytime six times in 3 years, although no special effort was made to watch for them except after floods. Further evidence for daytime activity were observations of a red-tailed hawk and a marih hawk with freshly-killed specimens at station 3 in mid-afternoon. The heavy predation on the rats by marsh hawks during the winters of 1958-59 and 1959-60 also attests to considerable exposure in the daytime or crepuscle. Correlation of nocturnal movements with weather conditions was imperfect because of the trapping methods used, traps being placed in the active houses.

From the above observations it appears the round-ta1led muskrat is primarily nocturnal, with peak activity occurring at evening crepuscle, although occastonal movement may take place during the day. A similar diel activity cycle has been reported by Dozier (1948) for ondatra.

\section{Seasonal Activity}

Round-tailed muskrats were more difficult to capture in warm weather, especially when luxuriant vegetation was present. The reason for this evident change in activity is not known. Erickson (1949) noted similar effects of hot weather on oryzomys captures and suggested a partial aestivation. Wragg (1953) trapped few ondatra during the summer in ontario. Comparatively few animals were seen, and sign was scarce. He suggested that many lived in inconspicuous nests at this time 
and fed only in sheltered locations, which were hard to find in the dense growth. In this study traps were placed in houses, but often in warmer weather the animals either failed to return to the house or pushed vegetation over the traps and into the exits. It is possible, therefore, that because of the abundant cover at this time of year, slight disturbances of the homesite caused animals to more readily abandon the house and to construct or move to another, and that this factor is responsible for the lower trapping success and apparent change in activity. 
FOOD

Porter (1953) listed the following plants as being used as foods by Neofiber in various parts of its range: Nymphea lutea, Sagittaria lancifolia, Pontederia sp., Mariscus sp..

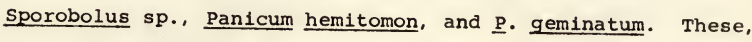
as well as Echinochloa sp., and Peltandra seeds were used in the Everglades (Schwartz, 1952). Harper (1927) reported that Neofiber in the okefenokee Swamp fed on stems of

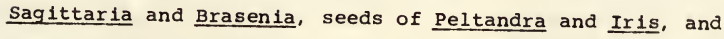
the roots of Anchistea. He suggested that the diet might be partly carnivorous on the basis of crayfish remains at feeding stands. Although crayfish remains were common on Neofiber feeding platforms on Paynes Prairie, these appeared to be attributable to oryzomys in all cases. No evidence of animal matter in the diet of Neofiber was obtained in this study.

In this study food habits were determined by the analysis of 330 stomach contents from animals taken throughout the year and from food remains recorded at feeding sites. The finely-macerated food particles in stomachs were identified only as to general type, 1.e., pith, roots, or epidermis. This could be determined by general texture and color of the remains under a binocular dissecting microscope. Some of the larger pleces could be identified to species, 
but a better indication of specific items eaten was obtained by examination of food remains on the platforms and in feeding shelters.

Maidencane constituted the principal food item of Neoflber on Paynes Prairie during all seasons. It was utilized mostly in the growing season, but underwater portions of the plant were eaten the year round. The stem was the portion of the plant eaten most often, the leaves usually being discarded. Other food recorded commonly were rice cut-grass, used primarily in early spring since it began growing early, and pickerelweed. The latter was used periodically throughout the year, but most commonly when 1t first appeared above the surface of the water in March. The epidermis and roots were the parts usually eaten. On one occasion pickerelweed pith was identified in a stomach, but strips of pith and leaves were usually discarded at the feeding site. Captive specimens devoured parts of the roots and the epidermis most readily.

Other plants eaten on occasion were Sagittaria lancifolia, Hydrotrida caroliniana, and Brasenia Schreberi. Sag1ttaria might have been a preferred food of considerable importance had it been more common. In the spring of 1960 several animals fed in a dense stand of this plant, about 50 feet in diameter, at station $A$. Twenty feeding pads were present at one time, and new ones were continually being built. Some individuals had to travel at least 100 yards to this feeding area, as only a few houses were present in the 
near vicinity. This was the only evidence obtained of Neoflber traveling any great distance to feed.

The rather restricted diet of the round-talled muskrat stands in contrast to the catholic tastes of many rodents. The limited number of food items consumed is, however, not surprising when the total number of plant species present in typical Neofiber habitat is considered. In the immediate vicinity of Neofiber workings only three grasses were common, and two were utilized. The third, Hydrophyllum carolinensis, does not develop the heavier, firm stems which would facilitate easy manipulation by the animals. Since the above grasses and pontederia are most common plants and are in plentiful supply, exploitation of further food sources is not necessary. Many of the other plant species tended to be of local and sporadic occurrence, and if Neofiber is a creature of habit, they might be neglected. In this connection Errington (1939a) stated that the diet of ondatra is determined largely by relative avallability of foods and by established feeding habits. Some populations that he studied were almost completely herblvorous, others carnivorous, their diets of frogs, fish, and molluscs varying only slightly from minks frequenting the same area. It is of interest that the abundant beds of Brasenia at Station $A$ were never used from 1958 unt 11 April 1961, at which times stems and leaves were eaten and incorporated into the houses. Hydrotrida stems and leaves were used extensively at station A as a supplementary material for house building. In contrast 
this plant was abundant at station 2, where 1 t was seldom used until the late winter and spring of 1961, when the muskrats began to incorporate it into their houses. These differences suggest the possibility of acquired feeding preferences in different Neofiber populations, which may be living in relatively close proximity. 


\section{MOVEMENTS}

\section{Home Range}

As noted previously Neofiber was difficult to live trap; and, since the animals were not attracted to bait, they could be taken with falrly regular success only inside houses. Since these circumstances necessitated destroying or damaing the structures, home range data could not be obtained by conventional live trapping methods.

As an alternative, some data on the movements of individual animals were obtained by the use of radioactive 1sotopes. Live-trapped animals were given intra-peritoneal injections of radioactive phosphorus, which is excreted in the feces and urine. Neofiber typically carries food from the water to feeding platforms or shelters where it is eaten. since the animals generally defecate while feeding at these stations, the platforms could be monitored with a Geiger counter to test for the visitation of an injected animal. A plotting of the feeding stations used by a given individual thus gave some indication of the area it utilized.

Prior to the field study, a captive was given an injection of P-32 in unbuffered water equivalent to 5 microcuries per gram of body weight. Feces and urine samples were checked dally for radioactivity. Readings taken 1 inch from feces samples registered at least 1.0 milliroentgen per hour or 
above for more than 9 days following administration, and radiation was detectable in the feces for at least 14 days. Radloactivity from the urine disappeared after 6 days. The excretion of $\mathrm{P} \rightarrow 32$ was uneven, particularly in the first 5 days following administration, but could always be detected. The relatively heavy dose used, based on an LD 50/30 days for laboratory rats and mice of about 4.5 microcuries per gram body weight (Sikov and Noonan 1954; Mewissen and Comar. 1959), caused no noticeable deleterious effects. The animal was seemingly in good health when killed 3 months later. Even so, the dose was reduced to 2 microcuries per gram of body weight on three of the wild Neofiber used.

Field experiments were conducted at Stations $1, A$, and B. The type and condition of the habitat were about the same in all areas. Emergent grasses and pickerelweed were just appearing above the surface; and the water, varying from 10 to 20 inches in depth, was nearly choked with submergent vegetation and debris. A total of 5 animals, 3 adults and 2 subadults, were live trapped and following weighing and examination were given intra-peritoneal injections of $\mathbf{p}-32$. The animals were released at the point of capture, and the general area was searched daily with a field model Nucleart Chicago Geiger counter, Model 2612. Since vegetation was sparse at this time feeding platforms and other structures were easily located and checked for radioactivity. Radioactive pellets were always removed from platforms to prevent reading them on a subsequent check. The animals were trapped 
from widely separated locations to preclude the possibility of overlap in home ranges of marked animals.

Data were obtained on four of the five marked animals; the fifth, a subadult female tagged May 3 was not found again. A total of 57 defecation sites were located in a 29night period following the releases, but no pellets were found on 8 nights during this interval. Comparing this with number of pellets excreted by captive animals indicated that not all pellets were deposited on the feeding platforms.

The feeding platforms known to be used by marked animals were generally quite close to occupied houses. The feeding range of one adult male, trapped and tagged at station 1, April 1, was particularly easy to follow and provided the most complete picture of individual movements of any of the specimens. Twenty-six positive readings and the occupied houses were recorded on 10 consecutive days. The first day pellets were found only at the point of previous capture. On the second day the animal constructed a new house 20 feet from the point of capture. It stayed here until April 6, when it built a new house 17 feet west of the point of capture. This house was still occupled when measurements ceased on the tenth day. In this period an average of three feeding platforms were used each night (range 0-5) in an area 42 feet in diameter. The entire range was used on four of the 10 nights.

The total area known to be used by all individuals averaged 0.012 acres, being equivalent to a circle about 30 
feet in diameter. Of the 57 platforms used, 25 (44 per cent) were within 10 feet of the house, 18 (32 per cent) 11-20 feet, 7 (12 per cent) 21-30 feet, and 7 (12 per cent) were 31-40 feet from houses known to be occupied. The animals used an average of 45 per cent of the total area on each of 9 nights when more than two pads were used. On 13 nights only one or two pads were used, and no range could be calculated. Three of the animals fed in an area less than 15 feet in diameter each night. However, when the abundance of food in this habitat is considered, the use of such small areas does not seem too surprising.

Some evidence indicates that the muskrats actually traveled over a larger area than that indicated by the deposition of radioactive pellets on the platforms. At Pond 1 , three or four individuals were occupying separate and adjacent feeding areas at one side of the pond. These could be delimited by size of pellets, the presence of radioactivity, and number of occupied houses. After the experiment the pond was trapped thoroughly to retrieve the tagged animal. The first night, five adults were taken from this area, and the tagged individual was not among them. Thus a minimum of six Neofiber was traveling on an area that contained three or four feeding areas.

In summary, these data indicate that Neofiber feed in an area close to the homesite, but may wander over a larger area, the size of which was not determined. Thus, the feedIng area calculated here does not represent a home range as 
ordinarily defined, but is only a measure of movement in regard to one activity, that of feeding. It is probable that the actual home range of the animals, though somewhat greater than the feeding area, is still relatively restricted.

\section{Territoriality}

I found no evidence for territoriality in this species except that only one adult animal occupled a house. Also, captives seldom permitted their nest box to be shared. Sharing of feeding platforms varied according to population densities. At Pond 1, where the first p-32 infected animal was released, a small population was present. Here, only rarely did more than one individual use the same pad in a single night. At Station $B$, houses were more numerous, and on several occasions at least three rats used the same pad on the same night. This might indicate that Neofiber exhibits no territoriality, and the use of houses by a single individual is an outcome of the solitary nature of the species. However, in any environment the potentially most limiting factor is the one usually defended (Dice, 1955). On the basis of this criterion, if Neofiber should exhibit territoriality, it would probably be in defense of the house rather than feeding areas, which were always plentiful. There was no evidence of defense of any area outside the house, and whether the house sites were defended was not determined. 


\section{Dispersal}

No actual measurements of the extent and magnitude of dispersal were made, but indications of this phenomenon were observed. Road kills were seen on several occasions, once one-fourth mile from the nearest known habitat, and another time more than one-half mile. The latter animal was near a ditch that drained into the nearest habitat. Rand and Host (1942) likewise recorded a male Neofiber killed along a ditch several hundred yards from the nearest pond. Therefore, it 1s probable that the animals often follow waterways when moving long distances.

Fourteen animals were toe-clipped and released at stations A and B. One adult male, first captured 3 May 1960, was taken in a trap on August 28 in a flooded pasture 40 yards from the point of initial capture. The animal probably was residing in nearly the same location before being forced to higher ground by rising water. No other individuals were recaptured.

During the first year of the study the rate of spread of populations, which might be considered as primarily the result of dispersal, amounted to no more than one-fourth mile during a breeding season. 


\section{POPULATION DENSITY AND COMPOSITION}

\section{History}

According to Dr. Archie Carr (personal communication), round-tailed muskrats were abundant on Paynes prairie during the 1930's. The four years from 1954 to 1957 were unusually dry, and many small ponds and marshes in north central Florida dried up. During this period Neofiber was extremely rare in the Galnesville region. Only a few of the deeper ponds on the prairie contained water, and apparently these had little emergent cover at the margins. More normal amounts of precipitation fell in 1957, and water conditions improved.

When I began this study in september 1958, Neoflber was found at station 1, with scattered colonies in the slough extending southward. The slough contained dense stands of Pontederia and was not ideal muskrat habitat. The animals also occupied the large marsh at station 2 and the disjunct ponds of station 3. Although no census was conducted, general observations indicated a heavy population. At this time, no round-tailed muskrats occurred at station $A$, and it was assumed that the populations were in the process of spreading from refuges in which they had persisted during the previous dry years. Although the locations of these refuges were not known, the areas occupied by the animals in 1958 indicated that they might have been along the deeper ditches in the 
center of the prairie or in the lakes of its eastern part. Populations were spreading toward the periphery, but had not yet reached station $A$ at the extreme western edge of the prairie. Both suitable habitat and deeper water existed here, and it served as a refuge during the summer of 1961, when most of the prairle dried up. Evidently it supported no Neofiber populations during the drought of the mid-fifties. Intensive reproduction took place during the fall and winter of 1958-59, and the population spread further. In March 1959, six new houses were found in flooded pasture along the edge of station $A$. The nearest colony from which these animals could have come lay on the other side of an old railroad embankment, 300 yards distant. No more animals spread into this area during the spring. The site was again surveyed in october, when 30 houses were present. The number of houses increased still more during the fall. By the spring of 1960 all suitable habitat in this marsh and on the entire prairie was occupied. Thus, in a period of four years the animals spread from probably small, circumscribed population units into all sultable habitat over an approximately 20 square mile area.

Below normal rainfall in the spring and summer of 1961 caused most of the shallow marshes to dry up, and the Neofiber populations were again confined to small refuges bordering the deeper ditches and ponds. More habitat remained than seems to have been present in the mid-fifties, and at least two areas with deep water held considerable numbers of 
Neofiber. These survivors were sufficient to repopulate nearly all areas of the study area, although in light concentrations, when rain flooded most of the marshed in early September 1961 .

Even when the entire prairie was populated with Neoflber, the species existed as a series of relatively isolated population units or colonies. The population at station 2, encompassing approximately 2 square miles of marsh, was by far the most extensive.

\section{Density}

The only previous mention of numbers of the roundtalled muskrat is from Harper (1927), who stated that the abundance of nests on Floyds Island Prairie in the okefenokee in June 1921 was almost beyond belief. In this study all expressions of densities of Neofiber refer to economic densities as defined by Elton (1932), and the population of Neofiber was computed only for the area in which the animals actually resided, not for the entire area of the prairie.

Seasonal maxima of populations on Paynes Prairie occurred from December through February. In February 1960 , one small area of 0.15 acres at station 2 was trapped intensively in an attempt to obtain quickly the resident animals. Traps were placed only in active houses. Twelve animals, not including three newly-born young, were taken from this area. One adult female with at least one partly-grown young escaped; and $s i x$ houses, two of which were definitely occupied, were not trapped. Thus at least 15, and probably 
18, animals were resident here, which indicated a density of 100 to 120 muskrats per acre at this locality.

A more extensive area was sampled by counting houses. on the basis of number of houses present the average population density for the entire marsh at station 2 was calculated at approximately 40 individuals per acre, to give a rough estimate of more than 100,000 animals in about 2,500 acres of suitable habitat. This value does not include the outlying sloughs and ponds, which constituted small additional areas of habitat, and the entire eastern half of the prairie. A crude estimate for all of Paynes Prairie placed the population at more than 250,000 animals.

Censuses based on house counts were also conducted on a small pond of 0.6 acres of Panicum-Pontederia habitat at Station 3 in the spring of 1959. In early March, 61 individuals were present, an economic density of 101 per acre. Because of flooding and poor cover conditions, the population dropped steadily during the spring to a level of approximately 12 animals or 20 animals per acre in early May. Sim1lar drops in numbers of Neofiber occurred over most of the prairie.

It is of interest to compare the densities recorded for Neofiber with those reported for other species of voles. Of all microtine rodents, the northern muskrat is probably the closest ecological equivalent of Neofiber. Population densities obtained for ondatra range from less than one pair to five pairs per acre (Johnson, 1925; Errington, 1940). 
Maximum biomass reported for ondatra approximates 23,830 grams per acre (Mohr, 1947). In the present study, with assumed peak density of 100 per acre and average welght of 250 grams, the biomass of Neofiber is 25,000 grams and greatly surpasses the values for other microtines, except during temporary eruptions in which animals soon decimate their food supply. There was no evidence that these densities of the round-tailed muskrat damaged their habitat.

Densities of muskrats and some other microtines equivalent to those recorded for Neofiber usually are accompanied by intraspecific stress or conflict which ultimately controls their numbers. Errington (1940) reported that when breeding densities of ondatra exceeded five pairs per acre (biomass approximately 9200 grams per acre), intraspecific strife was common. No increase in intraspecific strife was noted in the Paynes Prairie population. Thus, apparent lack of aggressive behavior in Neofiber under these conditions may be evidence of a different basis of population regulation in this species as compared to certain other microtines.

Porter (1953) suggested the possible existence of cyclic phenomena to account for drastic fluctuations in Neofiber populations. In 1952 he found animals scarce in two local areas in southern Florida and one in the okefenokee, where they had been reported abundant a few years earlier. In Porter's studies of Neofiber densities the intervals between observations were sometimes quite long. No long time, intensive census or study of populations have been made, and 
hence reports from the literature and personal communication provide only a fragmentary picture of any possible cyclic population changes.

Study of populations during the course of field work in this study did not provide evidence for cyclic phenomena or any regular long term changes. Although pronounced fluctuations occurred, these reflected changes in environmental conditions that are not regularly cyclic.

\section{Sex Ratios}

Males constituted 56 per cent of the total of 326 specimens collected. The slight preponderance of males occurred in each age group (adults, 56 per cent; subadults, 55 per cent; juveniles, 56 per cent). Sex ratios based on trapping data may often be distorted by sexual differences in activity or response to traps. In the present study this criticism seems invalid for traps were almost invariably placed in occupied houses, and the animals trapped upon return. Hence, possible differences in extent of movements by males and females should not be a factor in affecting the composition of the catch.

Seventy-five per cent ( 9 of 12) of the young born in captivity or brought into the laboratory for study were males. Although the ratio in this sample indicates a higher ratio of males at birth, the sample is small. The larger samples indicate a slight predominance of males, a phenomenon encountered commonly in other species. 
Sex ratios of fall-trapped ondatra vary from 48 per cent males (Marshall, 1937) to 69 per cent males (Buss, 1941). Beer and Truax (1950) reported a sex ratio of 56 per cent males based upon the ratios of 89,540 muskrats reported in the literature. When sex ratios were calculated separately for age classes there was an indication that females outnumbered males in adult samples, but males were more abundant in the subadult classes. These data on ondatra are in contrast to my results with Neofiber, in which males predominate in all age classes.

\section{Age structure}

Animals were classed as juvenile, subadult, or adult on the basis of pelage characteristics. The age composition of monthly samples of the Paynes Prairie population for 1959 and 1960 are presented in Figure 16. Since the general trends were similar in both years, the data were combined. Adults constituted the greatest percentage of the population from May through August, with generally lower numbers in the early and later parts of the year. The relatively higher incidence of juveniles and subadults at this time of year reflected the general breeding pattern during both 1959 and 1960. The lower percentage of juveniles compared to subadults at all seasons was probably due to the shorter juvenile period. The adult stage forms an even greater period in the life span.

High water levels and poor cover conditions, as det scribed earlier, resulted in little breeding and high mortality during the spring months. This resulted in a higher 
percentage of adults in the population. Intensive breeding began in August. Subadults began to appear in greater numbers in september and constituted from 25 to 45 per cent of the catch until the following May. Juveniles occurred in the samples in all months except May, June, and August, and reached their greatest numbers in December-March. 


\section{REPRODUCTION}

Few data have heretofore been available on the reproductive biology of Neofiber. Nest young or pregnant females were reported in January (Harper, 1927), February (E1l1ot, 1901). Apr11, and August (Moore, 1949). Porter (1953) presented additional records for January, June, and september, and surmised from his own and previous observations that reproduction in the round-tailed muskrat probably occurred throughout the year. He concluded that most young were born in the period from october to January and that two young were produced per litter. Hamilton (1956) obtained matings of Neofiber in captivity and described the newborn young based on two litters of two young each.

In this study reproductive data were assembled from analyses of age composition of the animals collected, necropsies, seasonal occurrence of breeding houses, and reproductive behavior in captive animals.

\section{Age and Cyclic Changes in Reproductive Organs}

Male

In young juveniles ranging in weight from approximately 50 to 150 grams, the testes were whitish, firm, and averaged approximately 4 by $3 \mathrm{~mm}$. In length and width, respectively. The tunica albuginea appeared smooth and opalescent, and the 
surface blood vessels were narrow and inconspicuous. Abundant fat deposits surrounded the testes. The cauda epididymides were not visible, and accessory glands were tiny. The vesicular glands were smooth, flaccld, light yellowish, and slightly translucent. They were about $7 \mathrm{~mm}$. long from the base to the antero-lateral flexure. The prostate gland was distinct, reddish to pink, and less lobulated than in the adult. Its length and width were approximately 6 by $3 \mathrm{~mm}$., respectively. The bulbo-urethral glands were nearly spherical, smooth, and about $2 \mathrm{~mm}$. in diameter. The preputials were 5 to $8 \mathrm{~mm}$. long and did not differ in appearance from those of the breeding adult. Their color was a dull yellow. The cremaster was not evident, the area between the penis and anus being fully ha1red.

Maturation of the reproductive organs paralleled the general growth of the male, and the increase in size of the genital organs occurred gradually. The testes and vesicular glands appeared to develop together, and the development of the other accessory glands was similarly correlated with testis size and activity.

In males classified as subadult on the basis of pelage development (200 to 300 gms. at 35 to 90 days of age) the testes averaged $8 \times 6 \mathrm{~mm}$. in length and width and $0.17 \mathrm{gms}$. in weight. The tunica albuginea was more cream-colored than in the juventle animal, and surface blood vessels were larger and more distinct. The cauda epididymal tubules were macroscopic in most testes at this stage. The vesicular 
glands averaged $18 \mathrm{~mm}$. in length, and their lobulations were more distinct. They had lost their translucence and were whitish to a light yellow. The prostates were of the same form, but deeper pink in color, possibly through increased vascularization. The bulbo-urethrals were more oval in shape, averaging $3 \times 2.5 \mathrm{~mm}$., but differed little in appearance from those of the juvenile. The beginning of the development of the cremaster was evident. The skin between the penis and anus was more thinly furred thanathe surrounding area, but as yet no pigmentation or reddening was present. The presence of sperm in the cauda epididymides of subadult males was variable. Eleven of 53 (21 per cent) subadults possessed sperm. In most only a few mature sperm were present. The testes ranged from $5 \times 3 \mathrm{~mm}$. to $12 \times 10 \mathrm{~mm}$. in size. The latter figure is near the maximum size attained in Neofiber. The testes that contained sperm were more than $8 \times 6 \mathrm{~mm}$. In size, except for those of one captive which were $7 \times 5 \mathrm{~mm}$. In size. Figure 14 shows the relation of testis size to body weight, age class, and fertility.

In fully matured males the testes were creamy white, averaging $10 \times 8$ to $13 \times 10 \mathrm{~mm}$. in size, and 0.30 to 0.50 grams in weight. The tunica albuginea was shiny, smooth, and its blood vessels were prominent. The gonad was not as firm as in the juvenile. The cauda epididymis was enlarged and the epididymal tubules distinct. Fat always surrounded the testis and epididymis. The vesicular glands appeared large, opaque, and creamy white. They measured 40 to $45 \mathrm{~mm}$. 
0
0
0
0
0

崩

章

깅

웅

담

다

곙

峛

㟧

5

ह

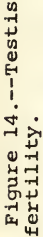

ฮี 


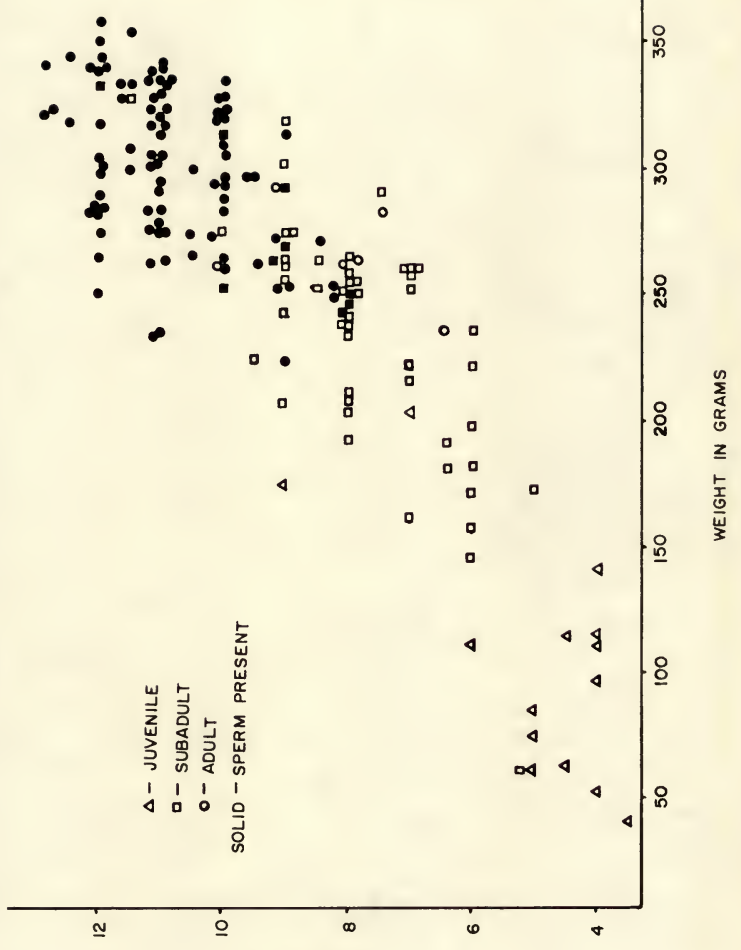

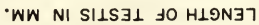


in length. The prostates resemble those of the subadult but were larger and with the individual lobes more distinct. The dorsal lobes averaged about $16 \times 8 \mathrm{~mm}$. In size. The bulbo-urethrals were about $4 \mathrm{~mm}$. In diameter. The preputials were usually large and flap-like, shaped somewhat like a right triangle and measured approximately $18 \times 6 \mathrm{~mm}$. This gland varied in size more than the other accessory glands. The cremaster was thinly furred in all adults but was not greatly swollen or consplcuous. When fully developed this area extended from the base of the penis to the anus and measured about $7 \mathrm{~mm}$. long by $5 \mathrm{~mm}$. wide. It never became completely halrless. Often the cremaster skin of adults was slightly tumid, and a small pigmented area was sometimes present in the center and rear of the thinly furred area. When present, this area varied from a mere trace to a circular black area 7 to $10 \mathrm{~mm}$. In diameter. Occasionally the tip (up to $5 \mathrm{~mm}$ ) of the glans penis was pigmented. The condition of the cremaster did not invariably reflect the condition of the testes. Occasionally, the cremaster of smaller adults was pigmented.

Although the "side gland" of Neofiber possesses no actual glandular tissue, the site of the gland is evident on the skin as a lighter and more strlated, oval patch. Bailey (1900) reported that degree of development of this area was associated with breeding activity. In this study 47 per cent of 108 adult male and 37 per cent of 87 adult female pelts showed the site clearly, but there appeared to be no 
correlation between reproductive status of adults and the prominence of the gland site. No seasonal trends were noticeable in development of this area, and the percentage of occurrence was irregular from month to month. The patch was not usually present in subadults.

Neofiber attains sexual maturity at approximately 90 to 100 days of age, at a usual weight of from 230 to 280 grams. Following sexual maturation, males did not appear to exhibit seasonal cycles in the reproductive organs. All but 5 of 112 adult males examined at different times of the year contained sperm in the epididymal tubules, and the genital tracts were enlarged. Only two of the non-fertile adults were fullsized individuals. They were taken in April 1959 and May 1960 when populations were presumed to be under higher than normal environmental stress. The other three were small individuals that had apparently completed the subadult molt earlier than normal. Figure 13 indicates that testes with sperm ranged in size from $8 \times 6 \mathrm{~mm}$. to $13 \times 9 \mathrm{~mm}$.

Regression of the male genital tract during prolonged periods of unfavorable environmental conditions seems possible, but was not observed in this study.

\section{Female}

The tubal genitalia of juvenile females were whitish, inconspicuously vascularized, narrow, slightly translucent, and flaccid. The uterine horns of 14 specimens ranged from 9 to $28 \mathrm{~mm}$. in length and from 0.5 to $1.5 \mathrm{~mm}$. in diameter, depending upon the size of the animal. The teats were never 
enlarged, and the vulva never perforate. The ovaries were tiny and exhibited no sign of activity except for the presence of minute follicles in some of the larger juveniles. Except for increase in size, the subadult and nulliparous adult tract appeared similar to the juveniles. They were whitish and still slender, but opaque. No vascularization was evident. The uterine horns of 22 non-breeding subadults averaged $32 \mathrm{~mm}$. In length, and the mean uterine width was $1.5 \mathrm{~mm}$. The uterine horns of two subadults in early pregnancy were $32 \mathrm{~mm}$. long, and those of one in a more advanced pregnancy were 38 and $40 \mathrm{~mm}$. In length. The teats of subadults measured about $1 \mathrm{~mm}$. In both diameter and length.

The uterine horns of 11 nonparous adults averaged $40 \mathrm{~mm}$. in length (32 to 48 ) and $1.9 \mathrm{~mm}$. ( 1.5 to 2.5 ) in diameter. Diameter of the vagina was $3.0 \mathrm{~mm}$. The vulva was imperforate, and the teats were about $1 \mathrm{~mm}$. In diameter and length, being difficult to locate beneath the dense underfur.

As in the case of males, females did not show any marked seasonal cycles in the development of the reproductive organs, and estrus cycles apparently occurred with the existence of favorable environmental conditions. However, individuals exhibited marked changes in the reproductive organs at different stages of the sex cycles. Females at or near estrus had a perforate and tumid vulva which sometimes was moist. Fitch (1957) used the perforate vulva as a crude index of breeding activity in Microtus ochrogaster. Approaching estrus was accompanied by enlargement and turgiaity of the tubal genitalia. The teats showed no change. 
The first noticeable change in the condition of the mammary tissue occurred early in pregnancy. Females reproducing for the first time possessed only slightly developed tissue, but in multiparous animals that had borne a litter recently the tissue might be pinkish, swollen, and fully developed by this time. The teats enlarged shortly thereafter, if breeding had occurred previously. In a tract containing two early stage embryos $11 \mathrm{~mm}$. In crown-rump length, the teats were slightly enlarged and turgid and measured 1.5 by $2.0 \mathrm{~mm}$.; but in several tracts with embryos up to $30 \mathrm{~mm}$. In length, half that at birth, the teats were small (1 $\mathrm{mm}$. by $1 \mathrm{~mm}$.$) and not turgid. During early pregnancy corpora$ lutea were conspicuous and measured up to 2.0 to $2.3 \mathrm{~mm}$. In diameter, near the maximum size at any time in the cycle. The vulva was perforate or lightly closed. The vulva was closed during most of pregnancy.

During late pregnancy the teats increased in length to approximately $3 \mathrm{~mm}$. The corpora lutea measured up to $2.5 \mathrm{~mm}$. in diameter. Mammary tissue had a greatly lobulated or granular appearance and was pinkish to cream-colored.

The round-talled muskrat possesses two pairs of inguinal and one pair of pectoral teats. In advanced pregnancy the inguinal tissue extended along each side in a band about $15 \mathrm{~mm}$. wide and $40 \mathrm{~mm}$. long. The pectoral tissue occurred on each side as an oval patch, $7 \mathrm{~mm}$. wide and $15 \mathrm{~mm}$. long, or was absent. The pectoral teats appeared to be nonfunctional. Porter (1953) reported that a captive litter of 
two used any of the inguinal teats. In all the litters of two observed by me only the rear pair of inguinal teats were suckled, and only the posterior portion of the mamary tissue was developed. Following weaning the mammary tissue became more yellowish in color and regressed rapidly.

In a specimen examined four days post-partum, the tract was still enlarged, but flaccld. The largest surface blood vessels were engorged, but the vascularization was not as diffuse as before parturition. Corpora lutea were large, but seemingly less developed than formerly. The placental scars were large and well-defined. Three wild-trapped females, with young of different ages, were examined, and time of parturition was estimated by comparing size of young with those of known age. At approximately eight days post-partum the tract measured $48 \mathrm{~mm}$. long by $2.5 \mathrm{~mm}$. In diameter, only a slight enlargement over the non-breeding condition. No vascularization was apparent except along the dorsal border of the uterine horn. At 15 and 20 days post-partum vascularization was absent, the horns were 48 and $43 \mathrm{~mm}$. long, and 2.2 and $2.0 \mathrm{~mm}$. in diameter, respectlvely. Corpora lutea were small, but distinct. These observations indicate that the female tract regresses rapidly, within a week following parturition. Placental scars remalned distinct approximately two months and nearly disappeared by three months post-partum.

\section{Breeding Seasons}

O'Ne1l (1949) states that ondatra reproduces throughout the year in Loulsiana, but little is known about breeding seasons of Neoflber. 
Data concerning the reproductive status of adult Neoflber collected each month from November 1958 to December 1960 are presented in Table 2. Since samples of adult females were small in some months, and similar trends in breeding were evident in each year, the monthly samples are combined in Figure 15. Pregnant females were taken in every month of one of the years except March. Heightened reproduction occurred in April and August, but maximum breeding took place in late fall. Lack of breeding in March was probably due to the poor cover conditions at this season, and in both of these years flooding serlously disrupted the Neofiber populations. No collections were made in March 1961, but breeding probably took place as evidenced by the presence of lined chambers in some of the houses. Normal water levels prevalled at this time, and pregnant females were collected in February and April when cover conditions were similar.

Further indication of times of reproduction could be obtained from the examination of age composition (Fig. 16). A few juveniles were taken in almost every month, but the number was slightly higher in fall and early winter. The proportion of subadults collected followed a similar pattern, but with an appropriate lag of one to two months.

From the above data there appears to be no well-marked seasonal breeding cycles in Neoflber. The periods of increased reproduction, apparent in Figures 15 and 16, were correlated with a decided increase in favorable cover conditions. During the period of study the prairie was flooded 


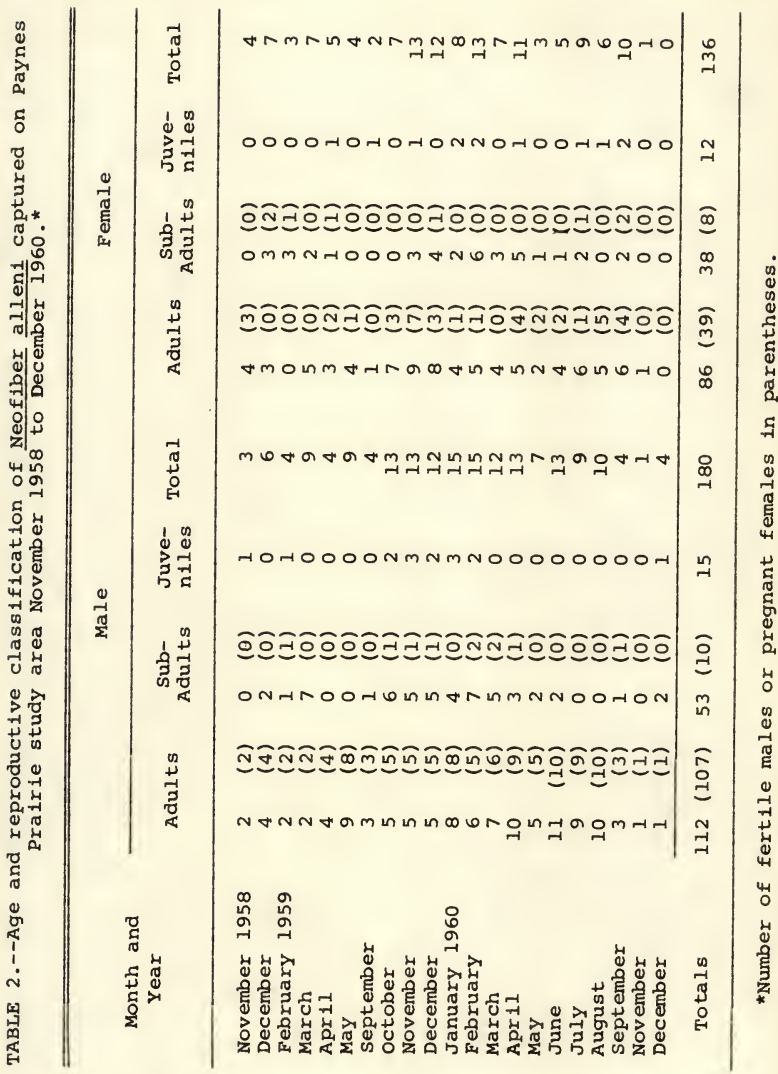




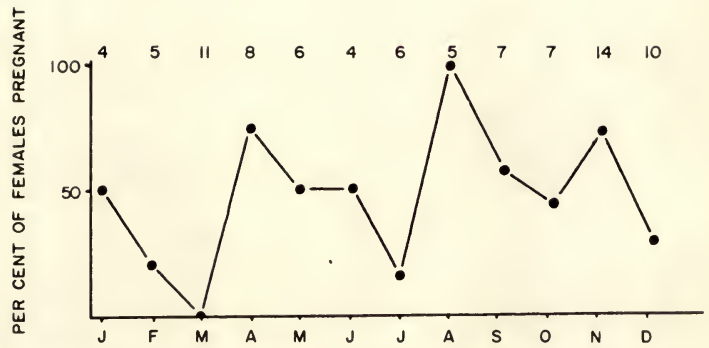

Figure 15.--Percentage of adult female Neofiber pregnant by month. Numbers at top of figure represent size of monthly sample.

adult $\square$ subadult $\square$ JUVENILE

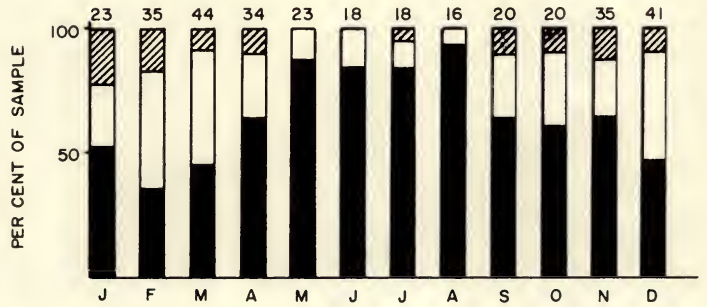

Figure 16.--Composition of monthly samples of all Neofiber allent collected from Paynes Prairie. Sizes of monthly samples are indicated at top of each bar. 
in March of both 1959 and 1960, when little or no emergent cover remained. Pregnant females were trapped in April when habitat conditions improved. High water levels prevailed in July 1960. Then in August habitat conditions improved, and pregnant females were again taken. The return of suitable conditions in the habitat seemed to stimulate intensive reproduction. Breeding was more general throughout the fall and early winter when emergent vegetation was most dense.

Evidence of temperature as a factor regulating breeding in Neofiber is not convincing. Average maximum temperatures in July were 90.2 degrees and in August were 90.7 degrees, yet breeding took place in the second and not the first month. If there were a cumulative effect from prolonged high temperatures, there should have been less breeding activity in August than in July. Thus, it is evident that high temperatures are not correlated with a cessation of breeding in Neofiber.

Since periods of reproduction were controlled by environmental conditions other than temperature, the development of plentiful emergent cover seems of greater importance. These conditions tended to exhibit seasonal periodicity during the study, but they may fluctuate from year to year. Even though a minimum amount of food is necessary to supply ordinary physical needs, dense growth may also provide food of higher or different quality, which might stimulate breedIng or, dense stands of grass may provide a psychological stimulus to breeding. This hypothesis is supported by the 
evidence that when cover is adequate throughout the year, the round-talled muskrat breeds throughout the year.

\section{Estrus Cycle}

Vaginal smears were taken dally for three weeks from one adult female, but cornified cells were found only on the first smear. Because reproductive behavior was sporadic in the laboratory, no further attempt was made to determine details of the estrus cycle by this method. However, indirect evidence indicates that the estrus cycle of Neofiber is about 15 days or less. The intervals between five of six litters of female No. 15 were $1-1 / 2,1-1 / 2,3$, and $3-1 / 2$ months. From the assumed gestation period of 26-29 days, the two intervals of 1-1/2 months indicate breeding of this female about 15 days after parturition or about the time the young were weaned. The remaining intervals indicate the same periodicity. However, it is possible that females have cycles that are some fraction of the interval suggested above. The interval of one month followed a still-born litter. This indicates that the female came in heat immediately following parturition. When the young were suckled, however, the cycles occurred about 15 days later. Field evidence substantiates these data in that no female was ever taken while simultaneously pregnant and nursing young. This also is evidence that a post-partum estrus does not normally occur.

\section{Mating Behavior}

Hamilton (1956) reported that an adult female accepted the male after a brief skirmish and that these animals 
shared the same nest box. I did not observe mating behavior in the laboratory or field. Adult pairs kept together in the laboratory never shared nest boxes and fought on most occasions when either attempted to enter the other animal's box. At no time did I observe members of a pair evidencing any interest in each other, despite the fact that six litters were concelved in captivity. My impression is that females are receptive to the males for only a short time in each estrus cycle, and that association between adults outside of this period is minimal.

\section{Gestation Period}

The only prior evidence on the length of gestation period of Neofiber was provided by Hamilton (1956) who found three new-born young 29 days after a male was removed from the female.

I obtained two relatively accurate records of length of gestation from captive female No. 15. Her fourth litter was stillborn 5 May 1961. She then gave birth to two normal young on May 31. These dates indicate that the pair mated shortly after partum and that the maximum gestation period was 26 days. On 13 August 1961, this female gave birth 29 days after her mate died. Hence, this gestation period lasted a minimum of 29 days. On the basis of these data, it may be concluded that the gestation period of Neofiber varies from approximately 26 to 29 days, which seems about average for animals of this size (Asdell, 1946). 


\section{Litter size}

The numbers of well-developed fetuses and recent placental scar counts provided data on the number of young per litter produced in the Paynes Prairie population. The mean number of fetuses in 48 gravid tracts was 2.3 , and the mean number of placental scars in 56 tracts was 2.1, giving an overall mean for the combined counts of 2.2. The frequency distribution of numbers of fetuses and placental scars is as follows:

$\begin{array}{cccc}\begin{array}{c}\text { Number of } \\ \text { Offspring }\end{array} & \begin{array}{c}\text { Number of } \\ \text { Individuals }\end{array} & & \text { Per cent } \\ 1 & 8 & & 7.7 \\ 2 & 67 & 64.4 \\ 3 & 26 & 25.0 \\ 4 & 3 & 3.0\end{array}$

Eleven litters born in captivity averaged 1.92 young per litter, with a range from one to three.

Several counts were obtained of the number of nursing young, based on trapping the mother with nursing young attached or on counting greatly swollen teats. The latter method may not be entirely accurate since Porter (1953) reported that the young changed nipples. As noted above, however, I did not observe this habit in my captive colony. The average number of young nursed was 2.1. The differences between counts of fetuses, placental scars, and nursing young are statistical significant and suggest a declining trend that might indicate pre- and postnatal mortality. However, the differences are not great. 
Corpora lutea counts from 46 pregnant females exhibited the following frequency distribution:

$\begin{array}{cccc}\begin{array}{c}\text { Number of } \\ \text { Corpora lutea }\end{array} & \begin{array}{c}\text { Number of } \\ \text { Individuals }\end{array} & \text { Per cent } \\ 1 & 1 & 2.2 \\ 2 & 16 & 34.8 \\ 3 & 24 & 52.2 \\ 4 & 4 & 8.7 \\ 5 & 1 & 2.2\end{array}$

This distribution gives a modal number of three scars and an average of 2.7 ova ovulated. This number is significantly different when compared with litter size, but indicates little ova loss through failure of fertilization or implantation.

Loss of fetuses after Implantation did not seem significant. In five of 51 pregnant females with measurable fetuses, the fetuses were of different size. Three tracts held two embryos, and two held more than two embryos. In one of the latter the three fetuses were attached in the same uterine horn, and the fetus lowest in position was the smallest. Size differential in crown-rump length was: $18 \mathrm{~mm}$. and $8 \mathrm{~mm}$.; $25 \mathrm{~mm}$. and $8 \mathrm{~mm}$.; $10 \mathrm{~mm}$. and $8 \mathrm{~mm}$; $20 \mathrm{~mm}$. and $16 \mathrm{~mm} . ;$ and $65 \mathrm{~mm}$. and $55 \mathrm{~mm}$. The small-size fetuses such as those found in four of the five tracts may be resorbed. In the remaining case, approximately near full term, a difference of $10 \mathrm{~mm}$. was measured. A similar size difference existed in a litter of three born in captivity. Although the smallest caught up to its littermates by six weeks of age, such runts may frequently die under natural conditions. 
only one actual case of resorption was noted. Thus, this factor probably does not account for a significant wastage of young. Dozier (1947) believed that it was rare in ondatra.

In summary, litter size in Neofiber averaged 82 per cent of the average number of ova produced. The possible resorption in 10 per cent of the tracts accounts for some of this loss, and most of this occurs in tracts with more than two fetuses. This evidence, along with the lack of total resorption of litters, leads me to belleve that the litter size of Neofiber allows for little variation in number of young per litter.

\section{Number of Litters per Year}

There are no published data on number of litters produced per year by Neofiber, but O'Neil (1949) states that ondatra produce five to six litters per year in Louisiana. Forty-two of 85 adult females in this study possessed no placental scars, and most of these were young individuals. of the 43 female tracts containing placental scars, 30 (70 per cent) contained one set, 11 (25 per cent) possessed two sets, and 2 ( 5 per cent) had three sets. Tracts containing two or more sets of scars were taken in october, November, December, January, February, March, and May. Th1s reflects the time when most breeding occurred. The maximum time that placental scars remain visible varies, but they were distinct and well-pigmented in one captive female six weeks postpartum. Two females, killed three months post-partum, contained faint, but distinct scars. The scars of another, 
which died in captivity and had given birth two months before, were almost invisible. Therefore, I considered that the presence of two distinct sets of placental scars represented the production of litters in the two-three month period prior to capture. On this basis, it appears that two litters may be produced in a three-month period, provided environmental conditions are appropriate. During this study, favorable cover conditions were present six to eight months out of the year; and, hence, four or five litters might be produced per female per year.

If environmental conditions were suitable year-round, the maximum number of litters, on an assumed 30-day gestation period, would be about eight litters. A captive female produced six litters, which were well-spaced throughout a one-year period. For reasons cited above and from occurrence of breeding houses, however, this maximum litter production was probably not attained by the Paynes prairie population.

\section{Natality}

The potential yearly natality of the female roundtailed muskrat is probably about 24 young. This assumes continuous breeding, producing eight litters of three young each. In comparison, realized natality of the Paynes Prairie population, based on a mean litter size of two, and four or five litters per year, is approximately eight young per year per adult female. 


\section{GROWTH AND DEVELOPMENT}

Porter (1953) and Hamilton (1956) have provided the only previous information on the growth and development of Neofiber. Porter described the general morphology and early development of two young live trapped with their mother, while Hamilton gave descriptions and weights of newborn young and reported the weight increase of a young male.

In this study five litters, totaling nine young, born to captive females and ralsed to adulthood provided data on growth and development. The development of these young was considered normal. An additional eight litters were not accepted by their mothers or did not survive for some other reason. Some of these young obviously were born prematurely, and data from them are thus not included in the descriptions which follow.

Pregnant females were kept in the cages provided with a wide-mouthed 2-quart jar for a nest box. During the first two to three weeks after birth the young nursed almost constantly and were difficult to detach from the mother's teats. Usually, I watched the cages after the animals were fed each evening, then removed the nest box with the young if the mother appeared outside. Two litters were not measured unt1l more than one week of age since they could not be removed from the mother. The other young were examined and 
measured daily during the first three weeks and approximately weekly thereafter. It was possible to examine and measure young without anesthesia prior to the opening of the eyes. When the eyes opened the young became more active, and it was necessary to etherize them for study. Young, as well as adults, recuperated readily without apparent ill-effects. At each examination weights and measurements were taken and the condition of eyes, ears, dentition, and pelage recorded. observations were made on general activity, behavior, and other details.

Litters designated as Numbers 1, 2, 3, 4, and 5 were from three different females, and all but No. 2 were sired in captivity by the same male. Litter No. 1 (1 young) was born 28 August 1960; No. 2 (1 young), September 21; No. 3 (3 young), December 4; No. 4 (2 young), 26 February 1961; and No. 5 ( 2 young), May 31. Litters 1, 3, and 5 were produced by the same female. She gave birth to other litters on or about 18 January 1961 (exact time of birth not noted), May 6 (1 dead young), and August 13 (2 young refused). Litter No. 2 was of a pregnant female captured 14 september 1960 , and Litter No. 4 was produced by a female live-trapped in August 1960.

\section{Growth}

The average weights and measurements of seven new-born Neofiber were $12.1 \mathrm{gms}$. (10.0-14.9 gms.); total length, $90 \mathrm{~mm}$. (85-94 mm.); tail, $21.0(20-22)$; hind foot, 12.0 (1213); and ear from notch, $3.5(3.5)$. Birth weights and 
measurements of young successfully raised in captivity were not obtained, since I hesitated to disturb the mother at this crucial time. The above data, therefore, were provided by seven specimens, born in the laboratory but refused by their mothers.

Growth of seven young from four litters is shown in Figure 17 (weights) and Figure 18 (4 linear measurements). Instantaneous rates of growth in weight, calculated at weekly intervals according to the equation of Brody (1945), are given for Neofiber and other microtines in Figure 19 and the values for linear measurements of Neofiber in Table 3. Since the measurements avallable for Neofiber were obtained at different time intervals, values for weekly intervals were calculated by interpolation from the curves in Figures 17 and 18.

Instantaneous growth rates were highest during the first week of life (1-3 days, 17.0 per cent; 3-7 days, 6.4 per cent), then decreased gradually to adulthood, except for an increase at weaning time. Figures for growth beyond the period in Figure 19 were avallable for only two individuals. Growth followed a similar trend until a welght of approximately 275 grams was attained at 95-100 days of age, at which time the animals became sexually mature. The ear and hind feet attalned full size early, at about 28 days of age. The relatively large feet were quite noticeable in the young. 


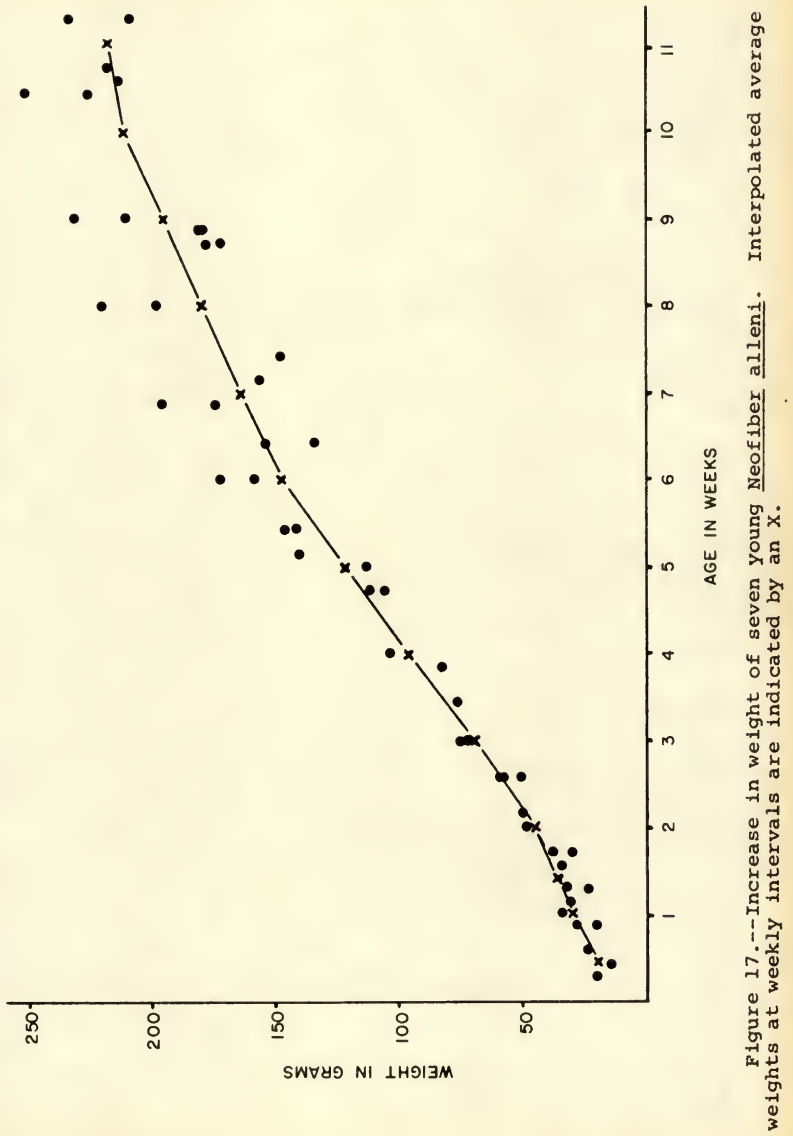



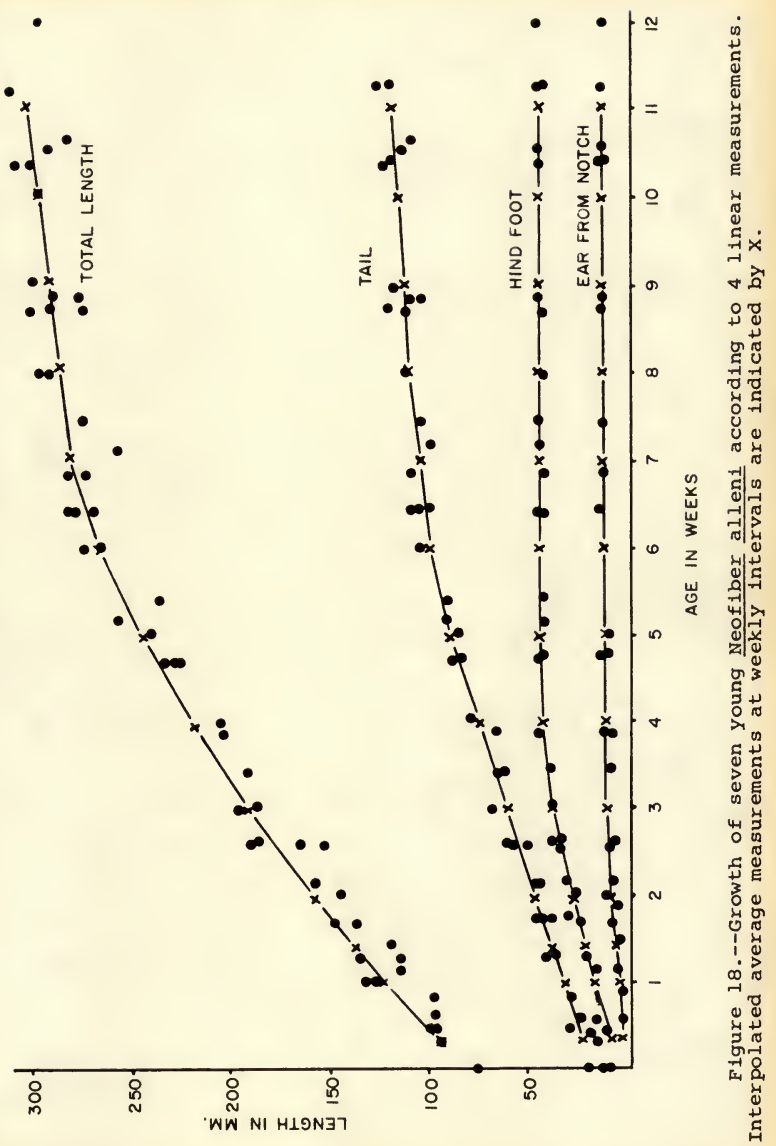


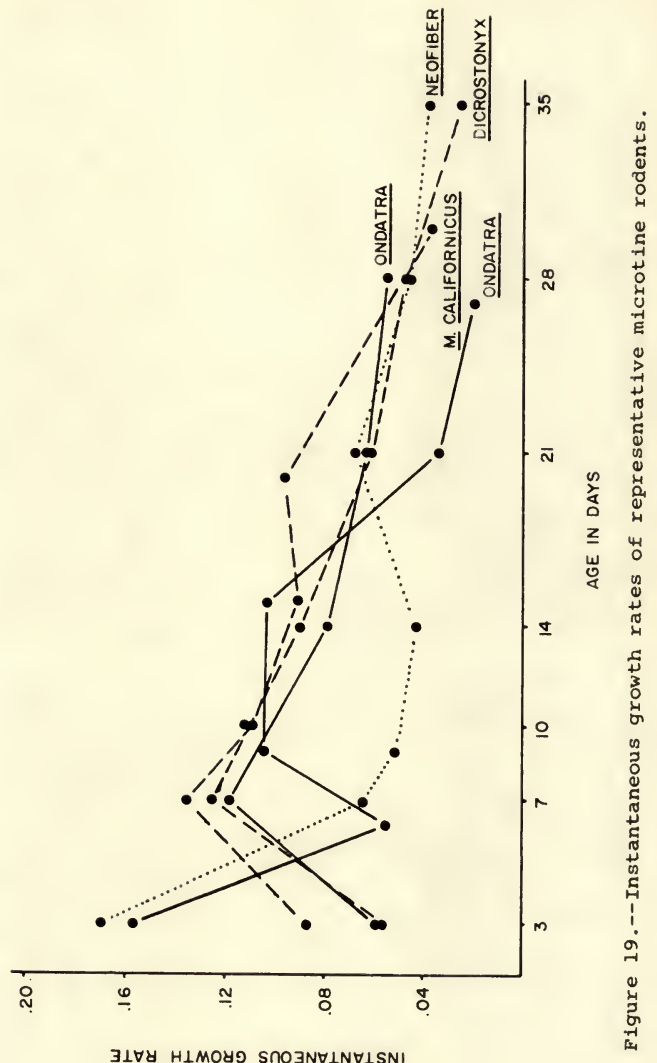


TABLE 3.--Instantaneous growth rates of seven young Neofiber alleni

\begin{tabular}{|c|c|c|c|c|c|}
\hline $\begin{array}{l}\text { Age in } \\
\text { Days }\end{array}$ & $\begin{array}{r}\text { Total } \\
\text { Length }\end{array}$ & Ta11 & $\begin{array}{l}\text { Hind } \\
\text { Foot }\end{array}$ & Ear & Weight \\
\hline 3 & .053 & .034 & .039 & .151 & .170 \\
\hline 7 & .041 & .090 & .124 & .022 & .064 \\
\hline 10 & .042 & .052 & .047 & .096 & .051 \\
\hline 14 & .036 & .049 & .040 & .056 & .043 \\
\hline 21 & .030 & .042 & .033 & .037 & .068 \\
\hline 28 & .019 & .032 & .016 & .011 & .046 \\
\hline 35 & .016 & .019 & .007 & .000 & .038 \\
\hline 42 & .012 & .018 & .007 & .010 & .024 \\
\hline 49 & .006 & .005 & .010 & .000 & .016 \\
\hline 56 & .004 & .020 & .000 & .000 & .017 \\
\hline 63 & .003 & .005 & .000 & .009 & .014 \\
\hline 70 & .002 & .004 & .003 & .000 & .012 \\
\hline 77 & .004 & .004 & .000 & .000 & .012 \\
\hline
\end{tabular}


Physical and Behavioral Development

Young Neofiber at representative ages are shown in Figure 20.

New-born Neoftber were blind, nearly naked, and helpless. The skin was wrinkled, especially on the sides of the body, and pink. A grayish tinge became evident on the sides and dorsum soon after birth, and grayish-brown hairs were visible without magnification within a few hours of birth. Vibrissae were well developed, the longest being approximately $5 \mathrm{~mm}$. in length. No teeth were extruded. The pinnae were sealed and folded to the sides of the head. The digits of both front and hind feet were only partially separated, and the claws were blunt, soft, and flesh-colored.

At two days of age the umbilicus had healed, but the anus was barely open. The incisors had extruded (.5 mm.), and the pinnae had unfolded. The sex could be determined by inspection of the external genitalia, the teats being visible on the females. The fur on the back and sides was dark gray or leaden to brownish gray, but the general aspect was grayish. The guard hairs were coarse and stiff, and finer underfur was also apparent. The young were still quite helpless, but the legs were thrashed freely and swiftly when the young were disturbed or removed from the mother. No crawling took place. The young attached themselves securely to the mother's teats. When disturbed, the mother sometimes bolted from the nest box and raced about the cage. The young remained attached, even though banged against cage projections, 
Figure 20.--Young Neofiber alleni. Scale on each photograph represents $50 \mathrm{~mm}$.
a. 3 days of age.
b. 7 days of age.
c. 30 days of age.
d. 45 days of age.
e. 67 days of age. 


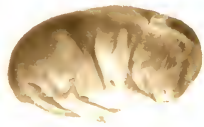

A

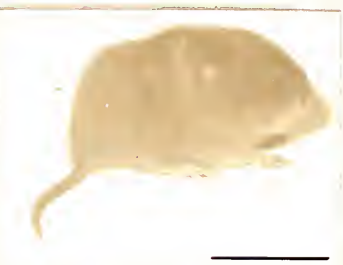

C

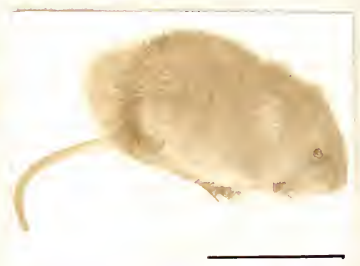

D

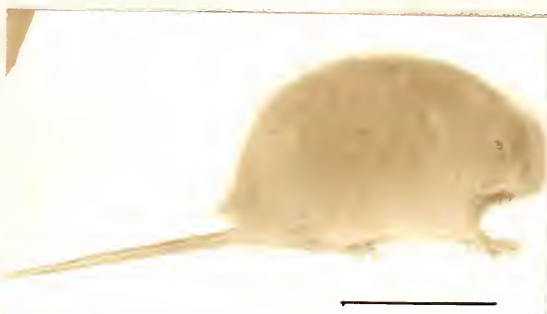

E 
water bowls, and the like. The adaptabllity of such behavfor is readily apparent in an aquatic species, since if removed from the mother outside the nest the young could not see or hear to orient themselves. Breeding houses that were opened in the fleld were nearly always found vacant; hence, I assumed the young were dragged from the house into the water with the mother. No observations were made on the survival or fate of such young.

At four days the umbilical scar was small, and only a dry scab remained. The upper incisors of one young measured $0.7 \mathrm{~mm}$. In length on the fourth and $0.8 \mathrm{~mm}$. on the fifth day. The incisors were still unpigmented. The pelage of the fourday old young was blackish, shiny, and dense on the dorsum and still quite coarse and stiff in texture. The hairs were sparse on the feet and tall, becoming more dense on the venter, where they ranged from light gray to dirty white. The coat still imparted a sleek, smooth aspect to the animals. They lay on their sides and struggled only slightly when handled. By this age the front legs were moved more actively and strongly, while less control was apparent in the hind legs.

Little additional development was evident at one week of age, except that the coat possessed a more brownish caste dorsad, and the venter was well furred. The fur was still coarse textured. The young did not walk readily, but dragged themselves about when released in the cage. I could detect no orientation in these movements. When they were placed in 
the hand, they would snuggle into creases as if searching for a teat. The limbs twitched only slightly every few seconds. By seven or eight days of age young fed by bottle groomed themselves in a manner similar to that observed in adults. This behavior consisted of washing the face and top of the head about the ears for approximately 30 seconds while in a crouched position. The animal then rolled on its side, grasped the hind leg with both front paws and cleaned each leg for about 15 seconds. Next, the groin area was groomed for about 5 seconds. Sometimes, grooming included only washing the face.

At 10 or 11 days of age young of one litter responded to a sharp squeak by jerking, indicating that the auditory meatus had opened. The molars still had not erupted, and the incisors were becoming yellow on the anterior surfaces. The pelage was now longer, nearly obscuring the ears and was dull and lax. The fur on the dorsum had brownish tips with lead-colored bases, which imparted a brownish caste to the pelage. The young were now more active, to the point of being difficult to measure. They continually rummaged about in the holding jar when confined for examination, but still could not find the nest box when released back into the cage.

The eyes of one litter opened at two weeks of age, and at 15 days and 18 days in two other litters. Three juveniles, captured at Station 1, 12 December 1959, were just opening their eyes at a weight of 40 grams. This weight was attained in captive litters at about 12 days of age, which lends 
support to an average age of about 14 days at the opening of the eyes. Two preserved juventles welghing 36 grams and estimated to be about 10 days of age had the full complement of molars erupted, although the lowers were barely above the gum line. Although it was difficult to ascertain the status of the molars on live animals, at least two erupted molars were seen and more were felt on one individual at 15 days of age and with a weight of 51 grams. The pelage now assumed a more brownish aspect of the late juvenile pelage. The postjuvenile molt usually was in progress. The young now were very active, bolting about the cage when an attempt was made to capture them. They still nursed regularly, but had begun to take solid fare also. Two wild-trapped individuals of this size contalned both vegetable material and milk in their stomachs.

By the end of the third week both upper and lower incisors were well plgmented, and the young were taking the normal adult food. The mother of litter No. 4 died when the young were 17 days old, yet both juvenlles continued to develop normally, a further indication of weaning by about three weeks of age.

By 30 days of age the post-juvenile molt had been completed and the typical brownish, subadult pelage was present. The young appeared and acted like minlature adults. They showed the typical defense posture when disturbed. Nursing was seldom noticed except when they were frightened excessively. Its occurrence under such conditions was suggestive of a displacement reaction. One 71-gram juvenile, caught in 
the same trap with the mother, was brought into the laboratory, where it nursed constantly. Juveniles of this size were nearly independent of the mother, so again, the nursing may have been due to fright.

At a month of age the young captives spent less time with the mother, and sometimes they occupied separate nest boxes. Two young of one litter were both occupying a different jar than the mother at an estimated age of 24 days. One juvenile of 78 grams and an estimated age of 21 days was taken in the same Conibear trap as the mother, indicating that it was still closely associated with her. Two juveniles, both welghing 123 grams and slightly more than one month of age, were taken under different conditions; one being taken in the lower part of a nursing house, while the other was captured in a small freshly built house, seemingly of its own construction. Hence, one of these animals may have been fully independent, while the other was still associated with the mother or the brood house. From observations made in the laboratory and the above, it seems that young Neofiber may remain with the mother until an age of four to six weeks, gradually becoming more and more independent. If post-partum breeding occurs, the minimal time must necessarily obtain. Interpolation of growth in the laboratory with sizes of trapped specimens indicates that the animals become sexually mature at from 90 to 100 days of age. I noticed no difference between males and females in this respect. A nearly equal number of subadults of each sex were fertile. A 
difference would exist in the age animals breed, since breedIng was apparently dependent upon the presence of suitable emergent cover. Most fertile subadults were collected when breeding was heaviest.

\section{Pelage and Molts}

Pelages and molt sequences of Neoflber have not been adequately described. Schwartz (1953), in his systematic revision of the genus, described juvenile transition, and adult pelages and theorized on the molt sequences.

In the present study molt data were obtained from captive animals and from an analysis of molt patterns of 186 flat skins and 110 conventional skins on which pelage condition had been recorded prior to preparation. The molt pattern often was difficult to see except by examining the inside of the skin for unprime areas. The patterns and sequences of molt are shown in Figure 21 .

\section{Post-juvenile molt}

Hair appears shortly after birth, and fuveniles molt between seven and 30 days of age. New halr usually appears first on the ventral midilne. The molt then extends evenly up the sides and toward the crown. The first molt took 10 days in one captive young and two weeks in another, but the scarcity of intermediate stages in fuvenile specimens collected in the fleld indicates that molt may be completed more rapidly in the wild. Twenty-three of 25 wild juveniles 
苟芒

牙䓀

(1)

ह

的

दै

ᄀ담

بै

언

ฮै

๓

ช 20

당

त 0

$x-1$

记

त्

क 0

-i.

c. 을

닥 5

咸

म्ञ है

계요 0

41.

이 동 명

द) 0

당ㄷㅇ

0

c)

(1) 0

\pm on

बा

त

+ 도

일

1)

1.

त成的

억

금대

का प्र

(1) $\frac{8}{\text { in }}$

\pm U 


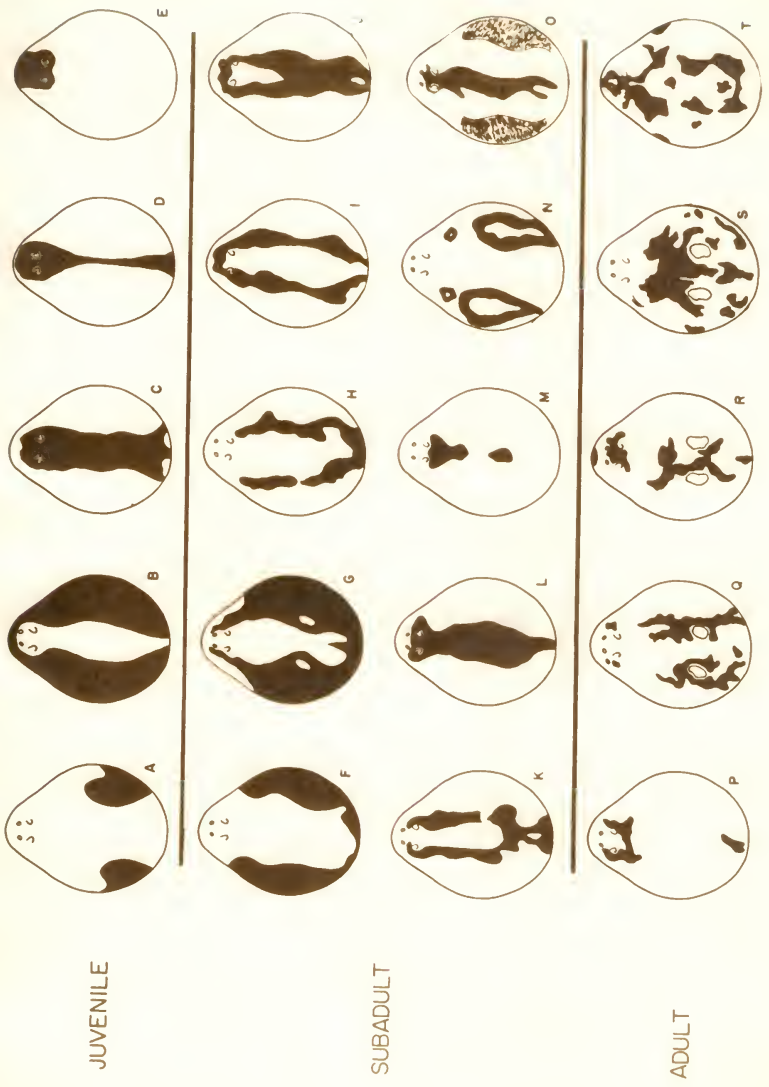


examined were either totally unprime or fully prime; only two showed the molt in progress. In some instances the new hair may appear almost simultaneously over the entire body. Following the post-juvenile molt the entire pelage gradually turns more brown. This transition does not correspond to the patterns of the previous molt and seems to be brought about partially by a change in color of the existing halrs. The tips of the longer halrs turn brown. As the brown segment lengthens toward the base of the halr, the brownish cast appears. The time of this transition in color varies considerably. Two young in the laboratory assumed the brown coloration at 40 grams in weight, although most wild-trapped juveniles were still grayish at this weight. Also, the guard hairs and underfur became more distinctive, the former were coarser and more glossy, the latter more dense and of a kinky or wooly texture on the belly. New guard hairs could also be seen by parting the fur. Hence, the new pelage is probably produced by both growth of new hair and changes in color and texture of old ha1rs.

\section{Subadult molt}

On the basis of three transitional pelts schwartz suggested that the subadult molt began laterally, perhaps ventrally, and gradually extended to the midline of the back. This interpretation is generally supported by the present data. The subadult molt begins at approximately 35-50 days of age, shortly after completion of the juvenile molt. The weights of seven captive animals ranged from 141 to 154 grams 
(age 36-44 days) when they commenced molting. Three captives kept until the molts were complete weighed 214, 219, and 230 grams, respectively, at this time. The molt lasted 24 to 30 days in these individuals. The minimum weight of wild animals beginning the molt and first classes as subadult was 137 grams, and most weighed between 140 and 160 grams. Maximum welght of subadults was about 230 grams, although it ranged up to 295 grams. The weights of most wildtrapped Neofiber undergoing the subadult molt compared favorably with the known-age captives in the same condition. However, the variability in time of molting precludes using it for specific aging as was done by Ecke and Kinney (1956) in Microtus cal1fornicus.

The molt begins by a gradual accumulation of pigment on the ventral midline (Fig. 21), but not including the legs or throat. In most specimens the new ventral hairs are not distinguishable from those of the late juvenile pelage, but in some the new hairs are lighter than the old ones. The molt typically proceeds up the sides in two lateral, long1tudinal bands extending from the tail to the jaw. These vary from $1 / 2$ to $1-1 / 2$ inches in width. The two bands first meet on the rump, then the shoulder area, moving more slowly up the sides of the head. This forms a dorsal stripe, widest in the region of the ears and becoming narrower posteriorly (Fig. 21, J and L). Molt is first completed on the rump, then proceeds forward. New hair appears on the crown last. The legs molt with the dorsal progression of the lateral bands. 
Several variations of the typical molt pattern just described were encountered. Two narrow unprime bands may move up the sides, merging to form only a narrow dorsal stripe or the bands may be much broader, or the entire side and back may be unprime. Also, one captive began molting on the ventral side, but after nine days the pelage became prime again. Two weeks later a normal molt began which was completed in 25 days. Two other captive subadults showed a partial molt on the belly seven days after completion of the subadult molt. These irregular waves of partial molting were encountered in several wild individuals (note F1g. 21, o). Hine (1960) has suggested that complimentary wave-1ike growths of hair gradually produce the prime condition in ondatra. In Neofiber it seems that such a phenomenon may occur occasionally or in addition to the normal molt pattern.

\section{Adult molt}

Adult molts are unpatterned, the replacement of hair being irregular and spreading from scattered centers. Such a pattern is common in microtine rodents, having been reported in Microtus (Hatfield, 1935), ondatra (Shanks, 1948), and Synaptomys (Connor, 1959). Little or no visible external difference can be noticed between the old and new fur. Although the starting points may vary, centers of molt are located in the lumbar region between the sites of the side glands (this center often spreads to the rump), the back and shoulders, crown, and the legs. The principal adult molt patterns encountered are illustrated in Figure 21, P-T. 
The duration and number of adult molts in Neofiber are not known with certainty, although schwartz (1953) suggested that adults may molt once a year. Approximately 68 per cent of the adults collected in this study were in some stage of molt. As a measure of the extent of molt the unprime areas on all adult flat skins were measured with a planimeter and this total divided by the total area of the skins. On this bas1s, the average extent of unprime area in the pelts of adults was 20 per cent. Figures 22 and 23 give the seasonal occurrence of incidence and extent of molt in the adult sample. These data indicate that molting occurs throughout the year, with an increase in the fall; but the duration of molt or number of complete molts per year was not determined. Lavrov (1944) states that adult ondatra molt continuously throughout the year and, therefore, invariably show a spotted pattern of primeness.

\section{Comparison of the Growth and Development of Neofiber with Other Microtine Rodents}

Growth

Using instantaneous growth rates, the growth rate of Neofiber can be compared with other species of microtines for which these data are available.

The growth rates for both Microtus, calculated from data of Hansen (1957), and Dicrostonyx, from selle (1928), increase in the three-seven day age interval, then decrease gradually until full size is attatned (Fig. 19). Microtus exhibits a slight increase in growth rate between 14 and 21 


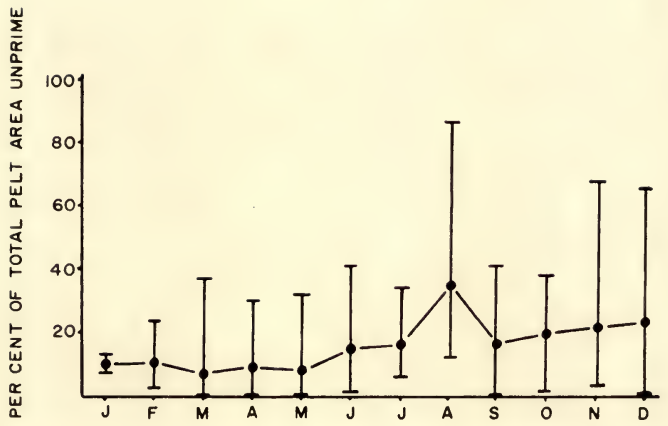

Figure 22.--Percentage of total area of all adult Neofiber pelts molting in each month of the study.

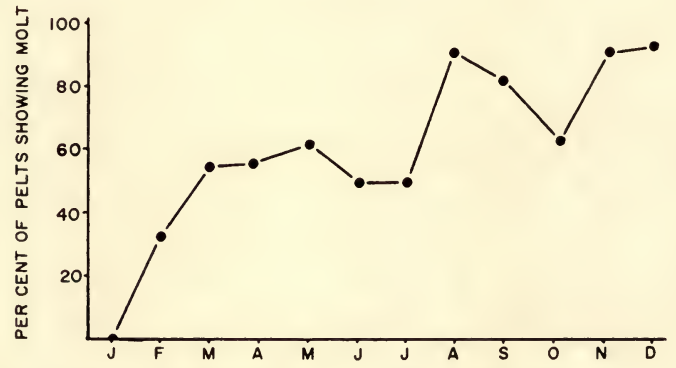

Figure 23.--Percentage of adult pelts showing some degree of molting in each month of the study. 
days, which is not present in Dicrostonyx and which may be attributed to a transition from a declining food source (milk) to a new one (solid foods). Otherwise the curves of the two small microtines are similar.

In contrast, the two larger microtines (Neofiber and Ondatra from data of Dorney and Rusch, 1953) grew relatively faster immediately after birth, but the rate decreased markedly in the three-seven day interval. Growth of Neofiber then declined slowly, being 2.4 per cent on the 42 nd day, and 1.2 per cent at 70 and 77 days. However, the growth rate of ondatra (Dorney and Rusch, 1953) Increased between seven and 10 days of age. This is too early for weaning, which, according to Errington (1939b), probably occurs early in the fourth week.

The differences in relative growth rates in the first week are difficult to interpret. One explanation for these differences may be that the large microtines do not recelve enough food from the mother to allow the increased rate of growth from three to seven days of age that is exhibited by the young Microtus and Dicrostonyx. The refore, the burst of growth in Neofiber and ondatra occurs earlier, when the young are relatively smaller. However, this does not explain the increases in rate of growth of ondatra (Errington's data, which did not agree with that of Dorney and Rusch). The growth curve of ondatra presented by Errington (1939b) is more like that of the smaller microtines than that of Neofiber or for ondatra based on the data of Dorney and Rusch 
(1953). Discrepancies also appear in other data from small microtines. Clethrionomys (Morrison, 1954) shows an even higher growth rate than Microtus from birth to three days of age (.210), dropping to .117 at from three to seven days. Conversely, Microtus pennsylvanicus (Ham1lton, 1941) shows a lower rate in the 0-3 day period (.077), then jumps to .204 in the 3-7 day interval. In general, the growth data ava11able on the smaller microtine rodents exhibit a growth pattern in the first week of life that is quite different from that of Neofiber, whereas the pattern for ondatra is inconclusive, since the two curves differ.

\section{Development}

Table 4 indicates the chronology of some developmental landmarks of the round-talled muskrat and five other microtines (Microtus pennsylvanicus, Clethrionomys gapper1, D1crostonyx groenlandicus, Phenacomys long1caudus, and ondatra zibethicus). All young rodents become independent early in $11 \mathrm{fe}$, but Neofiber ceased nursing at approximately the same time as many of the smaller rodents, and a week or more before ondatra and Phenacomys. From the above data it appears that most of the microtines compared are similar in respect to time of eye opening, ears becoming patent, and perhaps eruption of teeth. Neofiber departs from this schedule in that the teeth erupt earlier than in the others. The incisors extrude shortly after birth, the molars as soon or shortly thereafter. The young begin foraging when the eyes open and they are able to get about. This may be normal 


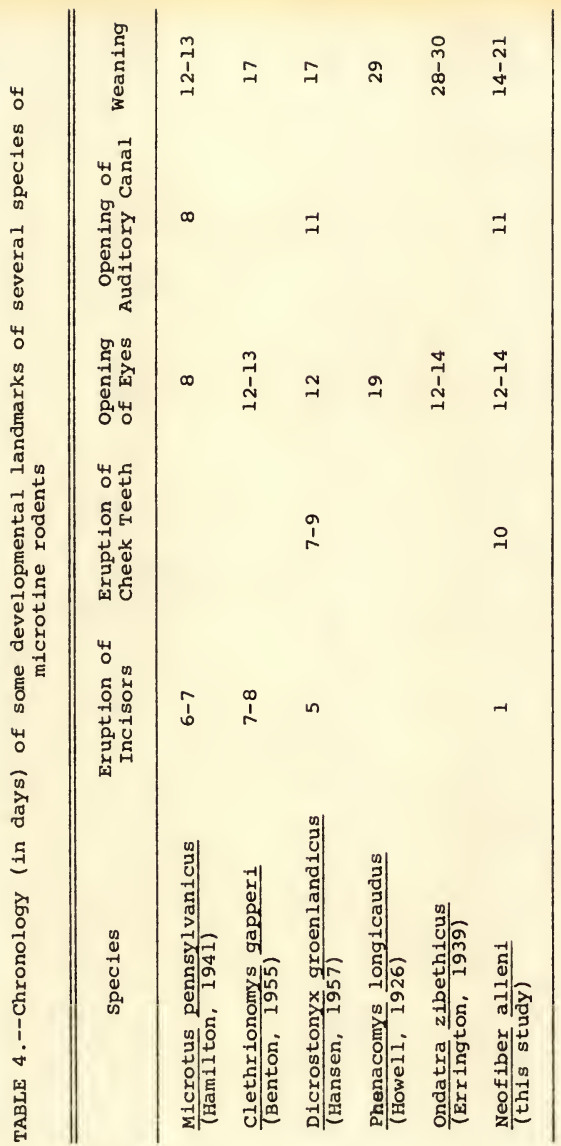


behavior for the smaller species, but young ondatra seem to be slower in this respect. Errington (1939k) reported that adult female ondatra may give birth to litters one month apart, and the young are forcibly evicted from the house. The larger Neofiber more closely resembles the smaller microtines in the time taken to become independent of the parent.

The relatively rapid rate of development of the roundtailed muskrat may represent an adaptation to the habitat and the type of homesite. The houses are of grass, and hence larger structures would not possess the structural rigidity and strength of the spherical, smaller houses. Hence, young Neofiber soon attains a size that precludes the use of a single house by a mother and her growing young. stage of development rather than rate of growth is the true measure of time needed for young to become independent of the parent. Both proceed hand in hand, but a young animal can develop rapidly and still not possess a greatly accelerated growth rate. This seems true of young Neofiber, and it allows this larger microtine to become independent faster when compared with related forms. 


\section{MORTALITY FACTORS}

Among the phenomena that may be considered as mortality factors in Neofiber populations are environmental fluctuations, predation, parasites and disease, and social interaction. All factors interact with each other in a complex manner, and none can exert its entire effect independently. It is thus difficult to assess the relative influence of particular mortality agents on the regulation of population size.

\section{Environmental Conditions}

Observations in 1959 and 1960 indicated that changes in water levels had drastic effects on Neofiber populations and hence are perhaps the most important environmental factor contributing to mortality.

\section{Flooding}

Normally, rainfall is heaviest in summer in the range of Neofiber. However, in March of both 1959 and 1960, near record precipitation fell on the study area. Water levels on the prairie were partially controlled by pumping and ditching, but these heavy rains caused up to an 8-inch rise in water levels (Fig. 24). A 2 or 3 inch rise was usually the maximum. The rains in March fell when practically all emergent vegetation of the previous growing season was gone, 
Figure 24.--(Upper) Study area at Station 2 after heavy rains in mid-March 1960. Note adult Neofiber on remains of house.

Figure 25.--(Lower) Heavy concentration of Neofiber houses in Panicum marsh at Station 2 in November 1959. 

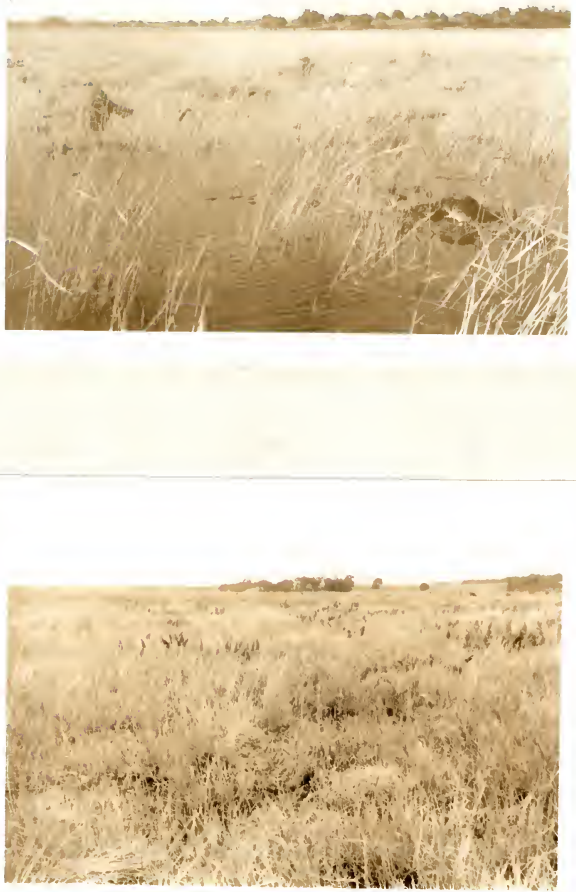
and new growth was just beginning to appear above the surface of the water. Much of the prairie was also affected because heavy grazing had reduced the grassy cover surrounding the ponds and sloughs.

At the beginning of this period high Neofiber populations were present (Fig. 25), but a steady decline followed flooding. An example of the magnitude of these changes was provided by weekly censuses on one pond at station 3. An estimated total of 61 animals was initially present. Heavy rains during the first part of the month raised water levels 2 inches by March 20, and the population dropped to a calculated 43 animals. No materials, to repair or build new houses were avallable, and the displaced animals disappeared. During the next two weeks the water level dropped 3 inches, then rose 2 inches. Populations remained about the same; 40 animals were present on April 4. During April average precipitation resulted in a slight decline in the water level, but damage to houses and lack of bullding materials caused most of the structures to become sodden and waterlogged. By April 18, only 26 animals were believed present. By April 23, the population on the pond was calculated as 12 animals. Cover was improving at this time, and new growth of panicum and Pontederia was incorporated into the old houses. Removal trapping carried on from May 9 to 12 indicated a population of about 10 Neofiber. Thus, a reduction of approximately 85 per cent of the population occurred on this pond over a period of $2-1 / 2$ months. 
The heavy precipitation ralsed water levels in the large center marsh, Station 2, 6 to 8 inches. All houses were flooded. Many displaced animals sought refuge along the road shoulders, and dozens were killed on the nearby highway.

A similar situation occurred a year later, when, on March 17, 1960, heavy rains again caused flooding of the prairie. High populations were present as in the previous year. The first night of water rise, 51 Neofiber were killed by cars on one mile of the highway crossing station 2 . Eight were collected by hand and nets on the levee road that night. Heavy predation and killing by cars on the highway occurred throughout the next week. By March 26 most surplus animals had disappeared, and the population at station 2 was estimated to have been reduced 50 to 60 per cent.

Populations were not affected equally on all parts of the prairie. Where grazing was not as heavy, or banks were present, more grass remained, and populations in those areas were not disrupted as much. For example, station B, 300 yards fram the study plot at station 3, had been grazed only lightly. Animals were repairing and building new homes in April, and at this site the heavy losses of station 3 did not occur. The animals found some protection on the levee road in the center of Station 2. Therefore, mortality rates of local population units varied considerably.

Younger age classes of Neofiber were most adversely affected by flooding. A total of 50 animals, collected by hand on roadways after flooding, were mostly juveniles and 
averaged 140 grams in weight. Trapping samples from relatively undisturbed habitats at this time averaged 260 grams. Errington (1937) indicated a higher vulnerability of younger age classes of ondatra to displacement.

\section{Drought}

Harper (1927) surmised that the round-tailed muskrat is more a bog-dweller than a truly aquatic rodent. Its ability to burrow and live in drier habitats has been described, but the adaptability of Neofiber to a more terrestrial habit has not been measured in terms of its survival value.

The effects of drought conditions on the Paynes prairie population was observed on two occasions. The shallow marsh at Station 2 nearly dried up in May and early June 1960. No open water remained, although water was present beneath the mat of organic debris that covered the bottom. Neofiber burrowed and lived beneath this mat (Fig. 26). Their tunnels and diggings could be observed by tearing away the vegetation, but the workings were visible where they opened onto the surface. Feeding occurred at these sites, but nests were not observed. Trapping success indicated that the animals were still relatively abundant. Rain began in mid-June, and the water returned to previous levels. I could detect little change in populations before and after this drought, which lasted approximately one month; but the marsh was not completely dry.

From May to August 1961, a more severe drought occurred. only 2.81 inches of rain was recorded in the Gainesville 
Figure 26.--(Upper) Panicum hemitomon habitat at Station 2 during dry period of June 1961. Note fresh burrowing beneath vegetation layer.

Figure 27.--(Lower) Area formerly containing deeper water at station $A$ in June 1961. The borders of these small pools served as refuges for Neofiber during drought. Note virtual absence of Panicum hemitomon. The abundant grass visible in the photograph is Hydrophyllum caroliniensis. 

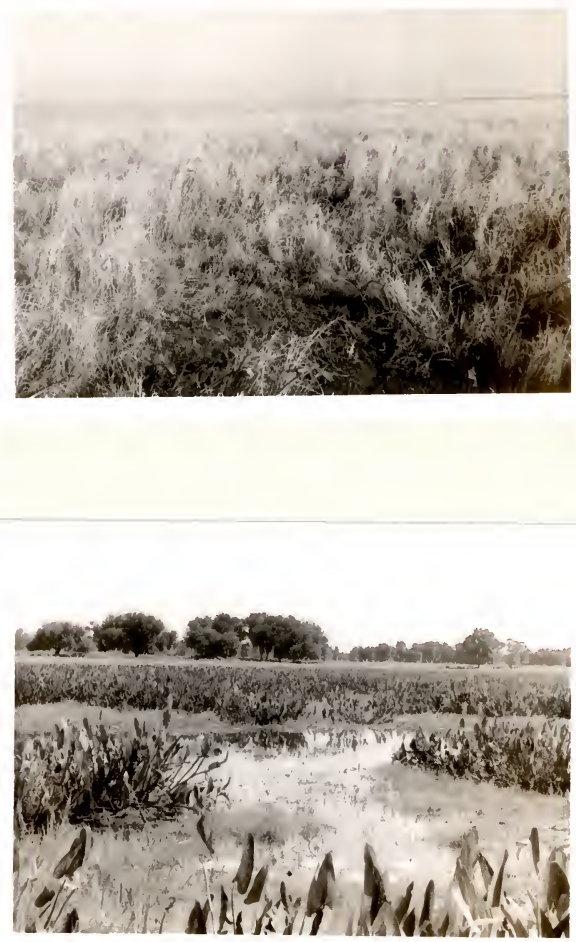
vicinity from May 1 to June 15, as compared to the normal average of 6.76 inches (U.S.D.C., 1953-57), and most of the study area dried up. By May 23, water levels were lower than at any time during the study. At station 2 water stood only in deeper holes beneat $h$ the vegetation layer. Here, feeding sign was noted, but few animals were present. At station A the maidencane border was dry, and the muskrat had been forced into the less favorable Pontederia zone (Fig. 27). Houses were numerous, but all had been constructed of Hydrophyllum. The fine-textured, small stems of this grass normally were not utilized if more suitable materials were available. No new houses were being constructed. On May 28 , Station 3 was dry, and muskrat sign was found beneath the vegetation mat only in two local areas. A few tracks and feeding signs were seen in the mud. Further checking in early June showed no rats in the marsh of station 2, except at one locality along the bank of a deeper pond in the center of the marsh and along the roadbanks bordering one side. on June 23, one feeding shelter was found along the bank of a deeper slough south of station 1 . Hence, in two months the Neofiber population on the study area had been reduced from a population of several thousand earlier in the spring to a few animals surviving along the edges of the deepest ponds and sloughs. When rains restored water levels in late August, only enough Neofiber were left to establish small populations in the most suitable habitats.

Most of this population reduction probably occurred through emigration, although actual evidence for this is 
slight. In early and mid-June 1961, snakes, mostly Natrix spp., migrated nightly from the southwest edge of paynes Prairie to a deeper prairie about $1 / 2$ mile south. The bulk of this mass migration, reported by Dr. J. A. Holman (in press) occurred across a short stretch of road where the two areas were in closest proximity. On June 10 an adult Neofiber was also seen crossing this stretch of road by Dr. Robert $\mathrm{H}$. Mount. No road kills were found, but the road was lightly traveled.

On Paynes Prairie the most suitable Neofiber habitat was the first to become uninhabitable when water levels dropped. The remaining habitat into which Neofiber were forced did not constitute preferred habitat. They formerly contained deeper water, and pickerelweed and Hydrophyllum constituted the emergent vegetation. Little of the preferred Panicum and Leersia was present (note Fig. 27). Neofiber was thus forced into this area where the water depth was sufficient, but the vegetation was not favorable.

Since the habitat of the round-tailed muskrat is similar to that of ondatra, the effects of environmental changes may be comparable. Changing water levels affected ondatra populations more than any other factor in the Illinois River Valley (Bellrose, 1941). He also reported that habitats most vulnerable to water fluctuations usually contained the most suitable vegetation for muskrats.

\section{Predation}

Although several instances of predation on the roundtailed muskrat have been reported, the significance of 
predation on populations has not been evaluated. Maynard (1895) observed a Ward's heron (Ardea herod1as) with a Neofiber in 1ts bill. Remains have been recorded in pellets of the barn owl (Tyto alba) by Howell (1932), Schantz and Jenkins (1950), and Schwartz (1952). In Georgia, Harper (1927) reported a domestic house cat with a specimen.

In this study a number of actual or potential predators on Neofiber were recognized. On Paynes Prairie most predation occurred during the winter months by the marsh hawk (C1rcus cyaneus). Although only three hawks actually were observed eating freshly killed specimens, evidence of their hunting was common in late winter. Visitant birds appeared in the Gainesville area in october and were abundant on the prairie unt1l April. Few kills were found in autumn when the profuse vegetation still offered protection. With the gradual breakdown of cover in December, kills were noted; and by February remains of Neofiber were common at station 2 . In late February 1960, muskrat remains were found approximately every 30 yards in one section of station 2 . The animals usually were eaten on the larger house tops.

Barn owls also preyed on Neofiber. After floods in March 1959 and 1960 had driven hundreds of animals to the tall grass of the road edge which led across the center marsh, barn owl predation reached high proportions. In most instances kills of the barn owls and marsh hawks could be distinguished by appearance of remains left. Roosts of barn owls that hunted on the prairie were not located even though 
likely roosting sites were searched regularly, and it seems likely that the birds came from a considerable distance.

Red-shouldered hawks (Buteo lineatus) were the most common raptor resident on the prairie. They were observed carrying snakes, and one was seen with a sora rail, but no evidence was found of predation on Neofiber. Red-tailed hawks (Buteo jamaicensis) were present in fewer numbers. On one occasion in April 1960, a red-tail was seen to capture an adult round-tailed muskrat on a slough near station 3 . Remains of one Neofiber were identified in a barred owl (Strix varia) pellet found under a live oak near the prairie edge on 10 December 1959. Twelve other pellets examined contained remains of sigmodon hispidus, oryzomys palustris, and Cryptotis parva. The bald eagle (Haliaeetus leucocephalus) was an occasional visitor on the prairie, but no evidence of their preying on Neofiber was noted.

Evidence of predation by mammalian predators included the bobcat (Lynx rufus); one scat in shallow marsh at station 2 on 20 February 1959 contained remains of two Neofiber. Bobcats patrolled the levee road regularly and evidently crossed the shallow marsh to bordering pasture land. Minks (Mustela vison) were rare; the only scat examined contained oryzomys and crayfish remains. otter (Lutra canadensis) scats examined contained only crayfish remains. Raccoon (Procyon lotor) and gray fox (Urocyon cinereoargenteus) were common, but no evidence of their preying on the round-tailed muskrat was found. 
Five of six cottonmouth mocassins (Agkistrodon piscivorus) collected on Paynes Prairie contained Neofiber; four of the six, examined 18 and 19 March 1960, contained a total of five muskrats. A 5-foot specimen from a nearby prairle in the fall of 1958 had consumed two adults. Cottonmouths were not abundant on the prairie. None was seen during the study except after flooding, when they were forced to roadways by high water. In areas where this snake is common, it should probably be considered an important predator of Neofiber.

During the period of study hundreds of houses were examined without any showing evidence of being torn open. It seems that Neofiber normally are preyed upon when away from their houses. The above observations showed that while some predation occurred in the warmer months, the bulk occurred in late winter and early spring which colncided with an abundance of prey and presence of less protective cover. Most predation was on flood-displaced Individuals, and hence was not a true indicator of its effect on stable populations. The first night following the 6 to 8 -inch rise in water levels at Station 2, the remains of eight Neofiber were found on $1 / 4$ mile of levee road. On March 19, 13 more k1lls were present. On March 26, the remains of 61 eaten animals were counted on this stretch of road; 190 on the entire two miles of roadway. Most of these animals were taken in the first six days, and only occasional remains were found after this time, even though Neofiber continued to live on the levee shoulder and barn owls and marsh hawks were st1ll present. This indicates 
that predation is a secondary factor with regard to reducing populations. Unsuitable environmental conditions such as high water and poor cover caused displacement of populations and allowed for increased predation or highway mortality to eliminate the displaced segments of the population. In areas where cottonmouth mocassins are abundant, they could possibly exert some effect.

\section{Parasites and Diseases}

Rausch (1952) and Porter (1953) have reported on parasites of the round-tailed muskrat. Rausch examined six specimens from Putnam County, Florida, and found two adult cestodes (Paranoplocephala neofibrinus and cittotaenia praecoguis) in the small intestine and one larval cestode (Taenla lyncis) in the liver. One species of trematode (Quinqueserialis floridensis) was present in the cecum. $\underline{\text { p. neofibrinus and }}$ Q. floridensis represented new species. Porter (1953) also recorded the two cestodes and the trematode in an unreported number of specimens. In addition, six of 12 Neofiber harbored the nematode Longistriata adunca. Specimens of Iitomosoldes sp. were found in the pleural cavity. Ectoparasites or commensals reported by porter were: Laelaps sp. (probably the same species later described by Tipton (1960) as Laelaps evansi), Trombicula splendens, Tyrophagus lintneri, and the mite predators Garmania bulbicola and Macrocheles sp.

In this study 123 of 298 round-talled muskrats $(41.3$ per cent) harbored helminths. Tapeworms were the most common ( 49.0 per cent), followed by flukes ( 13.1 per cent) and 
roundworms ( 6.7 per cent). A correlation between prevalence of infections and age was apparent. Prevalence of all helminths in juveniles was 16.7 per cent; in subadults, 52.8 per cent; and in adults, 67.0 per cent. No seasonal differences were apparent.

All tapeworms were found in the duodenum and were identified as Paranoplocephala neofibrinus by comparing stained specimens with figures in Rausch (1952). Most infections were light; 50 per cent of the infected Neofiber contained 1 tapeworm; 17.8 per cent, $2 ; 13.7$ per cent, $3 ; 6.2$ per cent, 4 ; and 12.3 per cent, 5 or more. Twelve individuals contained wads of as many as 20 worms that seemingly obstructed the intestine. No pathological effects appeared to be associated with these heavy infections.

All flukes were located in the wall of the cecum and were identified as Quinqueserialis floridansis parison with the figures in Rausch (1952). Infections were classes as light if less than 10 worms were noted, medium if 10-30 were evident, or heavy $1 f$ the cecal wall was spotted heavily with flukes. On this basis 18 (50 per cent) of 36 infections were 11ght, 13 (36 per cent) medium, and 5 (14 per cent) were heavy.

Nematodes, as yet unidentified, were found in the stomachs of 20 animals. Infections averaged three worms, a1though three animals harbored heavy infections.

Three species of mites, the only ectoparasites recorded, were 1dentified by Dr. R. W. Strandtmann. These included Laelaps evansil, Haemolaelaps glasglow1, and a member of the 
Listrophoridae, probably an undescribed species. Nearly all of the Neofiber examined were infested with mites.

Previous reports of disease-caused mortality in Neofiber are few. Harper (1927) reported that a subadult developed a paralysis of the hind limbs on the second day of captivity and soon died. Porter (1953) noted that his captives that died first became infected with sub-cutaneous cysts. Just before death the eyes became filled with mucus and closed. on one occasion, a litter of two young and their mother became infected and died.

I found no evidence of disease in any animals collected in the field or kept in captivity. In the first year of study some captives died, but their deaths were attributed to a dietary deficiency. Three animals died later, but the cause of death was not determined. All were in good physical condition, and showed no evidence of a pathogenic condition at autopsy. One of these, an adult male, had been kept for 20-1/2 months and died on the day or day after he mated successfully with a female. Occasionally a trapped specimen bore evidence of injury or wounds, but no evidence of disease. From the instances of parasitism and disease that were noted, it seems that these factors caused little if any mortality in populations of the study area.

\section{Social Interaction}

The only evidence of conflict between individuals was noted when one captive attempted to enter another's nest box. This resulted in the resident's rushing at the intruder with 
Its front feet clenched on the chest and teeth chattering. No actual biting was recorded. Conflict was evidently not common in nature, since little evidence of injuries was noted on specimens collected. Seven of 326 specimens had stub talls of different lengths, and seven possessed slightly torn pinnae; but none of these injuries was known to have been inflicted by other Neofiber. These results may be especially interesting as many animals were collected when population densities were high, and increased rate of injury might have indicated increased stress among individuals. There was no evidence for any intraspecific strife at these times. Evidently social interaction does not play a role in regulating populations or inflicting mortality on populations.

\section{Relative Roles of Mortality Factors in Population Requlation}

Environmental factors, specifically changes in water levels, appeared to be the primary regulators of populations. The manner in which populations were actually reduced varied according to the season and the specific habitat. In hab1tats where emergent vegetation was dense and tall, small fluctuations in water levels were countered by animals extending houses vertically or by burrowing in the bottom of the marsh. If the emergent vegetation was sparse, or fluctuations were drastic, all populations were displaced from their homesites. The animals were then exposed to other mortality factors such as predation or highway mortality. These factors were effective in reducing animal numbers 
until the habitat again became suitable or the surplus was removed. Under normal conditions they seemed to exert little influence on the animals. The proximate mortality factors that exerted some effect on populations always interacted with some abnormal environmental situation. 


\section{DISCUSSION}

The data of this study are of particular interest from the standpoint of their contribution to a better understanding of two aspects of the biology of the round-talled muskrat, namely: its restricted geographic distribution and its ecologic relation to ondatra, with which it formerly existed sympatrically and shares close phylogenetic ties.

Existing geographic situations such as shown by Neoflber are exceedingly complex. Only the seemingly most obvious and important factors can be discussed accurately or effectively. Physical geographic barriers, local climatic and vegetative changes, and possible interspecific relations combined over a long period of time to produce the situation as it exists today, but only a small number of these factors are recognizable or available for comment.

Neofibex alleni, the only surviving member of the genus, occurs today within a geographically restricted range that scarcely extends beyond peninsular florida. The range of the genus was more extensive in the Pleistocene, with Neofiber leonardi recorded from Kansas (Hibbard, 1943) and Texas (Meade, 1952), and Neofiber diluvianus from Pennsylvania (Hibbard, 1955). The living species differs only in minor modifications of the molars and in being slightly smaller than $\underline{N}$. leonardi, and 1 t is possible that the 
fossil forms will eventually prove to be conspecific with $\underline{N}$. alleni. Whether the Pleistocene representatives occupied more varied habitats than $\underline{N}$. alleni is not known, but the fossil forms are from deposits thought to be sangamon or Yarmouthian interglacials, which indicates climates were warm.

Several lines of evidence, including litter size, homesites, and population behavior indicate that the round-talled muskrat is a warmth-adapted species and thus is restricted to areas of warm climatic conditions. Litter size is low compared to that of most microtines. The typical number of young is two, and seldom are more produced. This agrees with the general tendency of animals with southern distribution to have smaller litters (Lord, 1960). The ultimate reason for this phenomenon may be a more equable distribution of energy expenditure. Antmals in lower latitudes have a longer breeding season and hence can produce more litters per year. For example, ondatra may produce five or six litters per year in Louisiana, compared with about two in the north. Since more time is avallable for production of young in the south, selection pressure may have favored smaller litters, which would put less physical strain on the females and perhaps increase chances of survival of young. Although total production of young would be the same on an annual basis, this would involve a more favorable energy budget by prorating the total energy expenditure of producing young over a longer period of time. 
The homesite of Neofiber appears adapted to a warm climate. The use of grasses for building houses precludes the construction of large lodges like those of ondatra. Therefore, the nests of Neofiber would probably not afford adequate protection to the animals in cold regions, since the plunge holes could not be kept open. The only possible alternative would be for Neoflber to move into drier habitats in winter, as in the case of Microtus terrestris in Finland (Artimo, 1960). Neoflber may possess too many adaptations to aquatic situations to thrive in terrestrial situations for long periods.

In general, microtine rodents are northern in their distribution. They usually have high reproductive potential and are effective in the utilization of foodstuffs. In northern areas over-exploitation of the food supply may cause serious long range effects because of the slow recovery of the vegetation. Therefore, selection has favored development of an intrinsic mechanism for reducing population densities before the food supply is destroyed. This is manifested in the cyclic phenomenon of forms tnarctic areas. The proximate factors seem to be some kind of stress producing a reduction or cessation of breeding or weakness and death of adults.

In more temperate areas food is not the potential limiting factor that $1 \mathrm{t}$ is in more arctic areas. The periodic cycles may be obscured, but under crowded conditions most microtine rodents exhibit stress which results in fighting and displacement of the less dominant animals. 
These activities, which are in response to an impending food shortage, might be projected further. If a group of animals evolved under conditions where food was plentiful and easily replaced, and if factors such as the weather regularly reduced populations by destroying or damaging the habitat, a mechanism for reducing population densities might have had a low or negative selective value. Such may be the case with Neofiber. In this study Neofiber exhibited no evidence of stress, conflict, or territoriality beyond the limits of the house, even when the biomass per unit of habitat surpassed that reported for other microtine rodents. Maximum densities recorded did not seem to over-exploit the food supply. However, the habitat of Neofiber is vulnerable to water fluctuations, especially flooding and lack of emergent cover. These environmental conditions seemed to be the primary agents in controlling populations by displacing animals which were then eliminated by various mortality factors. Thus, if the species had evolved under environmental conditions such as described, the self-regulating mechanism of control might be absent.

Provided the above ideas are valid, Neofiber may be restricted to its present range primarily because of adaptations to warm climatic conditions. Its formerly more extensive range may have been a result of climatic amelioration during pleistocene interglacials, which allowed range extension from an original southern range, or the animal may have evolved in higher latitudes when climates were warm. 
Genetic factors may also be involved in the restriction of the round-talled muskrat to a small area. One of three possible degrees of genic variability may have existed in the more widespread Pleistocene forms. Even though the genus was primarily adapted to warm, wet habitats, some populations may have possessed wide ecologic amplitude and existed in more terrestrial situations. Also, the genus may have existed in habitats similar to those in which it occurs today, but have possessed greater potential for dispersing and taking advantage of temporary unsuitable conditions. A third alternative is that the group was always narrowly restricted to a warm, wet habitat. In all of these cases the surviving populations that were presumably forced into the southeastern United States by glaciation may have represented only a small proportion of the original species with 1 ts potential variability. This situation may be comparable to that suggested by cain (1944) in discussing endemic floras. He suggested that a species can consist of a series of biotypes, each with broad ecologic amplitude, or a series of biotypes, each having a narrow amplitude. In either case the gene pool of all blotypes comprises the possible ecologic variability of the species. If the geographic distribution of the group was restricted by climatic change, the survivors might possess only part of the gene pool of the entire species, and thus exhibit narrow ecologic amplitude. Such a condition would reduce the effectiveness of the population to take advantage of opportunities for secondary range extension when and if the conditions arise. 
If the genus Neofiber formerly consisted of a series of races, probably only one or a small number of these forms survived in Florida. Under such conditions the restricted gene pool of the surviving population might not possess sufficient genic variability to allow range extension, through narrow habitat specificity and low dispersal, even though possible avenues for range extension became available.

In addition to the above factors, others may affect the geographic distribution of Neofiber. The vulnerability of its habitat to abnormal weather conditions hinders long term population build-ups and resultant pressures to disperse. In addition, the localized habitats in most parts of its range impede successful dispersal and range extensions. Also, the lack of intraspecific strife would limit dispersal and potential range extension because animals would not be forced into other areas. These factors may all be influenced by a restricted genotype which would hinder adjustment to new situations.

Studies of the skull (Bailey, 1900), baculum (Anderson, 1960), Meibomian and skin glands (Quay, 1952, 1954), and comparison of parasites and reproductive tracts in this study indicate that Neofiber closely resembles Microtus and ondatra, but in some cases is distinctive from both. Today the roundtailed muskrat does not live in close proximity to allied forms. Ondatra or Microtus range no further southeast than Louisiana, central Georgia, and South Carolina, though formerly they were present in Florida (Ray, 1957). The relationships between Neofiber and ondatra are potentially 
significant because of the present allopatric distribution, compared to the former sympatry, of the two species. In terms of habitats utilized, these two forms are more nearly ecologically equivalent.

Often the absence of one of two seemingly closely related species from the same geographic area suggests that they may be potential competitors. The problem is virtually untestable since many factors influence the success of an animal in a given environment, and all factors influencing two separate areas cannot be compared. The distinguishing features of niches are often too complicated or elusive to be thoroughly perceived (Errington, 1956). However, ecologic data that reflect potential differences in habitat selection would bear on possible niche diversification of the two species.

The results of this study and information in the literature suggest that the niches of Neofiber and ondatra may differ, especially with regard to vegetation utilized. Possible niche diversification is suggested in O'Ne11's (1949) description of marsh habitats in Louisiana. He indicates that the free-floating Panicum marshes, which resemble the Panicum prairies of Florida, are not preferred by ondatra. The muskrats do not construct typical lodges, but only throw up crude mounds and burrow beneath the layers of vegetation. The grasses are probably too fine-textured for building the larger ondatra lodges. The common muskrat normally utilizes coarse vegetation which may be necessary for construction of 
the lodge. The round-tailed muskrat utilizes grasses or sedges in construction of the homesite, and I never noted them using bulrushes, which ondatra seems to prefer. Hence, the two species may not be as potentially competitive as first impressions indicate. The presence of either of these forms in one area need not constitute the explanation for the absence of the other. 
SUMMARY

A study of the life history and ecology of the roundtailed muskrat (Neofiber allent True) was conducted on Paynes Prairie, near Gainesville, Alachua County, Florida, from October 1958 through August 1961. A total of 326 animals were utilized for analyses of catch composition, reproduction, and other aspects of the blology of this animal.

The most suitable round-tailed muskrat habitats were single dominant, shallow marshes with dense stands of panicum hemitomon or a Panicum-Pontederia lanceolata mixture. This vegetative composition was best developed where water was 6 to 18 inches deep and the substrate was sandy. The habitat was vulnerable to water level fluctuations.

The homesites consisted of tightly woven, nearly spherical, grass houses that were used by single adults, and feeding platforms and covered feeding shelters which might be shared. Houses provided some insulation from high summer temperatures and were used for periods up to six months, the time depending upon cover present and water levels. Animals burrowed beneath vegetation layers when marsh bottoms were exposed during drought.

Neofiber alleni was nocturnal, being most active at the evening crepuscle. The diet was entirely herbivorous, composed primarily of panicum hemitomon stems and roots. 
Males comprised approximately 56 per cent of all age classes. Round-tailed muskrats attained sexual maturity when approximately 90-100 days of age and at a weight of 230280 grams. Males remained fertile after becoming mature. Breeding was correlated with the presence of favorable water levels and cover conditions. On the study area most reproduction occurred in the late fall and early winter. The gestation period was calculated to be 26-29 days. Litter size averaged 2.2 in 104 females. Average number of ova produced was 2.7. Pre-natal loss seemed insignificant. Realized number of 11 tters per year appeared to be four or five for a realized natality of approximately elght young per year.

Growth and development were recorded for four litters, totaling seven young that were born in captivity. The young averaged 12.0 grams at birth. The incisors extruded at two days of age, molars at about 10 days, and the eyes opened at about 14 days. The young were weaned by three weeks and were independent of the mother thereafter. A juvenile, then subadult molt, obtained the adult pelage. Adults molted throughout the year with an increase occurring in fall. In comparison to other microtines, young round-tailed muskrats seemed to resemble the small microtines in rate of development.

Data on home range were obtained by injecting animals with radioactive phosphorus, then determining feeding areas by locating radioactive feces on the feeding platforms. Four animals restricted their feeding to an area about 30 feet in diameter. They wandered over a larger area. 
Maximum densities of Neofiber approximated 100-120 an1mals per acre of habitat. No evidence of intraspecific stress was noted under these conditions.

Populations seemed to be regulated by environmental conditions, primarily water level fluctuations, which altered the habitat. Predation by raptors reached high proportions after flooding, but was a minor and normally secondary mortality factor. The young were more adversely affected by displacement than adults.

Helminth parasites were found in 41.3 per cent of the specimens examined. Tapeworms were the most common parasite (49.0 per cent), followed by flukes (13.1 per cent) and roundworms ( 6.7 per cent). Parasitism or disease did not seem to be an important mortality factor. Mites, the only ectoparasites found, were present on nearly all specimens examined. Litter size, homesite construction, and population behavior indicated that the round-tailed muskrat is a warmth adapted form that is probably restricted to its present range primarily by climate. Range extension is probably impeded by the localized habitats within 1 ts range, low rate of dispersal, and lack of intraspecific stress in the species. It is hypothesized that Neofiber might be ecologically separated from ondatra if the two species existed sympatrically. 


\section{LITERATURE CITED}

Anderson, Sidney. 1960. The baculum in microtine rodents. Univ. Kans. Publ., Mus. Nat. Hist. 12:181-216.

Artimo, Atso. 1960. The dispersal and acclimatization of the muskrat, ondatra zibethicus (L.), in Finland. Papers on Game Research, Finnish Game Foundation, Helsinki. $101 \mathrm{pp}$.

Asdell, S. A. 1946. Patterns of mammalian reproduction. Comstock Publ. Co., Ithaca, New York. 437 pp.

Bailey, Vernon. 1900. Revision of American voles of the genus Microtus. North Amer. Fauna No. 17.

Baker, Frank C. 1889. Remarks upon the round-tailed muskrat, Neofiber alleni, True. Proc. Acad. Nat. Sc1. Phil. pp. 271-273.

Bangs, outram. 1898. The land mammals of peninsular Florida and the coast region of Georgia. Proc. Boston Soc. Nat. Hist. 28:157-235.

Bellrose, Frank C., and Lou1s G. Brown. 1941. The effect of fluctuating water levels on the muskrat population of the Illinois River Valley. J. Wildl. Mgt. 5:206-212.

Beer, James R., and W. Truax. 1950. Sex and age ratios in W1sconsin muskrats. J. Wildl. Mgt. 14:323-331.

Benton, A. H. 1955. Notes on the behavioral development of captive red-backed mice. J. Mamm. 26:566-567.

Brody, S. 1945. Bloenergetics and growth. Reinhold Publ. Corp., New York. 1023 pp.

Buss, Irven 0. 1941. Sex ratios and weights of muskrats (ondatra zibethicus zibethicus) from Wisconsin. J. Mamm. 22: $403-406$.

Cain, Stanley A. 1944. Foundations of plant geography. Harper and Brothers, New York. $556 \mathrm{pp}$.

Chapman, Frank M. 1889. On the habits of the round-tailed muskrat (Neofiber allen1 True). Bull. Amer. Mus. Nat. Hist. 2:119-122. 
1894. Remarks on certain land mammals from Flor1da, with a list of the species known to occur in the state. Bu11. Amer. Mus. Nat. H1st. 6:333-346.

Connor, Paul F. 1959. The bog lemming (Synaptomys cooper1) in southern New Jersey. Mich. State UnIv. Mus. Publ. $1: 161-248$.

Dorney, Robert L., and A. J. Rusch. 1953. Muskrat growth and litter production. W1sc. Cons. Dept. Tech. Wildl. Bu11. 8:1-32.

Dice, Lee R. 1955. Natural communities. Univ. of Mich. Press, Ann Arbor. 547 pp.

Doz1er, Herbert L. 1947. Resorption of embryos in the muskrat. J. Mamm. 28:398.

---1948. Estimating muskrat populations by house counts. U.S. Dept. Int. Circ. 18:1-42.

Ecke, Dean H., and Alva R. Kinney. 1956. Aging meadow mice, Microtus californicus, by observation of molt progression. J. Marm. 37:213-222.

El11ot, D. G. 1901. A 1 ist of mamnals obta1ned by Thaddeus Surber in North and South Carolina, Georg1a, and Florida. Fleld Col. Mus. Zool. Series 3:31-57.

Elton, Charles. 1932. Territory among wood ants (Formica rufa L.) at Picket Hill. J. Animal Ecol. 1:69-76.

Errington, paul L. 1937. Drowning as a cause of mortality in muskrats. J. Mamm. 18:497-500.

1939a. Reactions of muskrat populations to drought. Ecol. 20:168-186.

- 1939b. Observations of young muskrats in Iowa. J. Mamm. 20:465-478.

- 1940. Natural restocking of muskrat vacant habitats. J. Wildl. Mgt. 4:173-185.

- 1956. Factors limiting higher vertebrate populat1ons. Sc1. 124:304-307.

Erickson, Arnold B. 1949. Summer populations and movements of the cotton rat and other rodents on the Savannah River Refuge. J. Mamm. 30:133-140.

Eyles, Don E., and J. Lynne Robertson. 1944. A guide and key to the aquatic plants of the southeastern United states. U.S. Public Health Service Bull. No. 286. 
Fitch, Henry S. 1957. Aspects of reproduction and development in the prairie vole (Microtus ochrogaster). Univ. Kans. Publ., Mus. Nat. H1st. 10:129-161.

Hall, E. Raymond, and Kelth R. Kelson. 1959. The mammals of North America. The Ronald Press Co., New York, 2 vols. $1083 \mathrm{pp}$.

Hamilton, w. J. 1941. Reproduction of the fleld mouse (Microtus pennsylvanicus ord). Cornell Univ. Agr. Exp. Sta. Mem. 237.

1946a. Habits of the swamp rice rat, oryzomys palustris palustris (Harlan). Amer. Midl. Nat. $36: 730-736$.

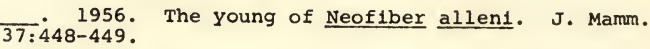

Hansen, R1chard. 1957. Development of young varying lemmings (Dicrostonyx). Arctic 10:105-117.

Harper, Francis. 1920. The Florida water-rat (Neoflber allent) in the Okefenokee Swamp, Georgia. J. Mamm. $1: 65-66$.

- 1927. Mammals of the okefenokee Swamp region of Georgia. Proc. Boston Soc. Nat. Hist. 38:191-396.

- 1935. Records of amphiblans in the southeastern states. Amer. M1dl. Nat. 16:275-310.

Harris, Van T. 1953. Ecological relationships of meadow voles and rice rats in tidal marshes. J. Mamm. $34: 479-487$.

Hatfield, Donald M. 1935. A natural history study of Microtus californicus. J. Mamm. 30:1-8.

Hibbard, Claude W. 1943. The Rezabek fauna, a new Pleistocene fauna from Lincoln County, Kansas. Univ. Kans. Sci. Bull, 29:235-247.

1955. Notes on the microtine rodents from the Port Kennedy cave deposit. Proc. Acad. Nat. Sci. Phil. 107: 87-97.

Hine, Ruth L. (Editor) 1960. Research in Wisconsin, a technical digest of research results in fish management, forestry and game management (1959). Wisc. Cons. Dept. 104 pp. (mimeo).

Hitchcock, A. S. 1950. Manual of the grasses of the United states. U.S. Dept. of Agri. Misc. Publ. 200. $1051 \mathrm{pp}$. 
Howel1, A. B. 1926. Voles of the genus Phenacomys. II. Life history of the red tree mouse (Phenacomys long1caudus). North Amer. Fauna No. 48.

Howell, A. H. 1932. Florida bird life. Florida Dept. of Game and Fresh Water Fish, Tallahassee. 579 pp.

Johnson, Charles E. 1925. The muskrat in New York: 1ts natural history and economics. Rossevelt Wildl. Bull. $3: 190-320$.

Laessle, Albert M. 1942. The plant communities of the Welaka area. Univ. of Florida Biol. Sci. Series 4 : 1-143.

Lavrov, N. P. 1944. Fur structure and molt in Fiber zibethicus. Trans. Central Laboratory of Biol. of Game Animals, People's Commisarlat for Procurement, U.S.S.R. $6: 164-183$.

Lord, Rexford D., Jr. 1960. Litter size and latitude in North American mammals. Amer. Midl. Nat. 64:488-499.

Marshall, William H. 1937. Muskrat sex-ratios in Utah. J. Mamm. 18:518-519.

Maynard, Charles J. 1895. The birds of eastern North Amer1ca. rev. ed., printed by author. $721 \mathrm{pp}$.

Meade, Grayson C. 1952. The water rat in the Pleistocene of Texas. J. Mamm. 33:87-89.

Mewissen, D. J., and C. L. Comar. 1959. The effect of cystamine on acute radiotoxicity of $\mathrm{p}^{32}$ in mice. Nuclear Med. 1:47-53.

Miller, Gerrit S. 1896. Genera and subgenera of voles and lemmings. North Amer. Fauna No. 12 .

Mohr, Carl o. 1947. Table of equivalent populations of North American small mammals. Amer. Midl. Nat. $37: 223-249$.

Moore, Joseph C. 1946. Mammals from Welaka, Putnam County, Flor 1da. J. Mamm. 27:49-59.

1949. Putnam County and other Florida mammal notes. J. Mamm. 30:57-66.

Morrison, P. R., F. A. Ryser, and R. I. Strecker. 1954. Growth and development of temperature regulation in the tundra redback vole. J. Mamm. 35:376-386. 
O'Ne11, Ted. 1949. The muskrat in the Louisiana coastal marshes. Louisiana Dept. of Wildilfe and Fisheries, New Orleans. 152 pp.

Porter, Raymond P. 1953. A contribution to the life history of the water rat, Neofiber alleni. M. S. Thesis, Univ. of Miami. $84 \mathrm{pp}$.

Pournelle, George H. 1950. Reproduction and early postnatal development of the cotton mouse, peromyscus gossypinus gossypinus. Ph. D. Thesis, Univ. of Florida. $78 \mathrm{pp}$.

Quay, Wilbur B. 1952. The skin glands of voles and lemmings (Microtinae). Ph. D. Thesis, Univ. of Mich. $153 \mathrm{pp}$.

1954. The melbomian glands of voles and lemmings (Microtinae). Univ. of Mich. Mus. Zool. Misc. Publ. $82: 1-82$.

Rand, A. L., and Per Host. 1942. Mammal notes from Highlands County, Florida; results of the Archbold Expeditions. Bull. Amer. Mus. Nat. Hist. 81:1-21.

Rausch, Robert. 1952. Helminths from the round-tailed muskrat, Neofiber alleni nigrescens Howel1, with descriptions of two new species. J. Parasit. 38:151-156.

Ray, Clayton E. 1957. A 11st, bibliography, and index of the fossil vertebrates of Florida. Publ. No. 3, Fla. Geol. Survey. $175 \mathrm{pp}$.

Rhoads, S. N. 1902. The marsh or rice-field mice of the eastern United States. Amer. Nat. 36:661-663.

Schantz, Viola S., and James H. Jenkins. 1950. Extension of the range of the round-tailed muskrat, Neofiber a11eni. J. Mamm. 31:460-461.

Schwartz, Albert. 1952. The land mammals of southern Florida and the upper Florida Keys. Ph. D. Thesis, Univ. of Mich. $182 \mathrm{pp}$.

- 1953. A systematic study of the water rat (Neoflber alleni). Univ. of Mich. Occas. Papers Mus. 2001 . 547:1- 27 .

Selle, Raymond M. 1928. Microtus californicus in captivity. J. Mamm. 9:93-98.

Shanks, Charles E. 1948. The pelt-primeness method of aging muskrats. Amer. Midl. Nat. 39:179-187. 
Sikov, Melvin R., and Thomas R. Noonan. 1954. Studies on the acute effects of $\mathrm{X}-1$ rridation and $\mathrm{P}-32$ on 21 and 32 day-old rats. Contract w-7401-eng-49, Atomic Energy Project, Univ. of Rochester.

Smal1, John Kunkel. 1933. Manual of the southeastern flora. Science Press Printing Company, Lancaster, Penn. $1554 \mathrm{pp}$.

Stone, W. 1898. Occurrence of oryzomys palustris in southern New Jersey. Proc. Acad. Nat. Sci. Phil. pp. 480481 .

Tipton, Vernon J. 1960. The genus Laelaps; with a review of the Laelaptinae and a new subfamily Alphalaelaptinae (Acarina:Laelaptidae). Univ. Cal. Publ. Ent. 16:233356.

True, Frederick w. 1884a. A muskrat with a round tail. Sc1. $4: 34$.

- 1884b. On a new muskrat, Neofiber alleni, from Florida. Proc. U.S. Nat. Mus. 7:170-172.

- 1885. The Florida muskrat (Neofiber alleni True). Rept. U.S. Nat. Mus. pp. 325-330.

Ulmer, F. A., Jr. 1944. Further notes on the rice rat in Delaware. J. Mamm. 24:411.

U.S. Dept. Agr1. 1941. Climate and man. Yearbook of Agriculture. U.S. Gov't. Printing office, Washington. $1248 \mathrm{pp}$.

U.S. Dept. Commerce, Weather Bureau. 1953-1961. Climatological data for Florida, Annual summaries. Ashville, North Carolina.

Van Doren, Mark. (Editor) 1928. Travels of William Bartram. reprinted by Dover Publ. 414 pp.

Wragg, L. E. 1953. Notes on the life history of the muskrat in southern ontario. Can. Field Nat. 67:174-177. 


\section{BIOGRAPHICAL SKETCH}

Dale Eugene Blrkenholz was born 13 February 1931 at Prairie City, Iowa. He recelved his elementary and secondary education in the prairie City public schools. From 1950 until 1952 Mr. Birkenholz attended McPherson College, McPherson, Kansas; then he served for two years in the United States Army. After his discharge, he entered Iowa State University where he recelved a Bachelor of Science Degree in Zoology in 1956. He received a Master of Arts Degree from Southern Illinois University in June 1958. In September 1958 he entered the University of Florida to begin work on the degree Doctor of Philosophy.

Dale Eugene Birkenholz is unmarried. He is a member of Sigma X1, Ph1 Sigma, the American Soclety of Mammalogists, the American Ornithologists' Union, the Ecological Society of America, the wildiffe Society, and the wilson ornitholog1sts' Club. 
This dissertation was prepared under the direction of the chairman of the candidate's supervisory committee and has been approved by all members of that committee. It was submitted to the Dean of the College of Arts and Sciences and to the Graduate Council, and was approved as partial fulfillment of the requirements for the degree of Doctor of Philosophy.

February, 1962

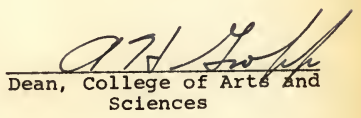

Dean, Graduate School

Supervisory Committee:

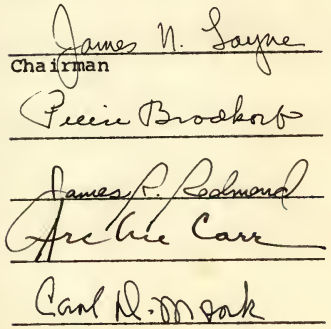

